\title{
La perspectiva de género en la historia social y jurídica de la criminalidad: un balance bibliográfico
}

The gender perspective in the social and legal history of crime: a bibliographic balance

\author{
Victoria Sandoval Parra \\ Profesora Contratada Doctora de Historia del Derecho \\ Departamento de Historia Jurídica y de Ciencias Penales y Criminológicas \\ Universidad de Murcia \\ E-mail: vsp461@um.es
}

A día de hoy, la definición y delimitación histórica del concepto de género presenta enormes dificultades, habida cuenta de que, en esencia, la perspectiva de género se ha desarrollado fundamentalmente desde un punto de vista social y cultural solo ya avanzado el siglo XX. El problema principal de su proyección histórica reside en la demarcación de las materias o los problemas que invitan, en efecto, a una inclusión de la idea de género como análisis del tratamiento discriminatorio que social y culturalmente ha padecido el sexo femenino y en superación de las cualidades intrínsecas que tradicionalmente fueron asociadas biológicamente a la mujer, sin olvidar el perfil de aquellos temas que, de forma contraproducente, al intentar ofrecer una perspectiva de género — quizá influidos por una falsa necesidad de asimilación por razón de actualidad - no contribuyen más que a la desvirtuación y alteración de la cuestión analizada, con riesgo de anacronía, que por lo demás incluso puede afectar al propio término.

Desde esta perspectiva, todavía se antoja más discutible si la idea de género puede ser útil para un enfoque histórico-jurídico y en particular criminal. La respuesta es compleja y parte de la constatación de la difícil adaptación de una noción cultural y vulgar (en un sentido estricto) a un ámbito de tratamiento técnico y complejo como el que corresponde a la disciplina de la Historia del Derecho penal. De hecho, existe un evidente problema conceptual derivado del concurso de un gran número de tipos delictivos cuya comisión, en la práctica jurídica, se inclina primordialmente hacia un 
sexo u otro. Sucede así en los crímenes de infanticidio, aborto, rapto y violación, estupro, prostitución, adulterio, brujería y hechicería, en los que, o bien el tipo delictivo entraña un protagonismo exclusivamente femenino, o bien afectan generalmente, en su casuística, a la mujer. A pesar de esta circunstancia, no es casual que estas figuras delictivas hayan dado lugar, en un balance de la producción científica, a una bibliografía propia delimitada de un modo exclusivamente institucional, sin prejuicios subjetivos; la complejidad técnica de estas materias jurídicas, a pesar del peso de la condición femenina en su naturaleza, las ha consolidado como instituciones marcadas por la estructura de su consideración legislativa, doctrinal y judicial, mediante una terminología y un sistema de enfoque técnico pericial que se sobrepone a un punto de vista sociológico de género. Dicho de una manera más directa, parece que corresponde a la Historia social y cultural el estudio del concepto de género. A partir de este criterio puede sostenerse la atención al género por parte de la Historia jurídica en el sentido amplio de la investigación multidisciplinar, como uno de los factores interpretativos de la Historia social que, sobre todo en relación con la práctica jurídica, puede tener relevancia para hacer más profunda y contrastada la valoración de los mecanismos propios del estudio de la Historia del Derecho.

Combinando estas apreciaciones, por una parte este trabajo reúne 469 trabajos sobre la cuestión de género ligados al ámbito de la criminalidad, donde se cruzan interdisciplinarmente aportaciones bibliográficas de la Historia social y de la Historia jurídica. Por otra parte, se ha excluido la bibliografía que formaría parte de un relación exclusivamente institucional de las figuras delictivas antes citadas: una bibliografía sobre crímenes concretos que debería completar la perspectiva de género a partir de una delimitación previa de los crímenes en los que se valora la frecuente incidencia de la discriminación femenina.

Dicho esto, y a propósito de la bibliografía seleccionada (siendo imposible, obviamente, que pueda considerarse completa), un $26 \%$ trata sobre el tema de la violencia de género, incluyendo también denominaciones como violencia "conyugal", "doméstica" y similares; se incluyen en este porcentaje la violencia femenina en el ámbito familiar, y el maltrato femenino en general, social e históricamente. Un 18,3\% de los trabajos se centra en el ámbito jurídico-criminal propiamente dicho, a saber, el tratamiento criminal de la mujer desde el punto de vista sustantivo (sujeto activo del delito en particular), y los procedimientos y las sentencias judiciales. Un 11,1\% de la bibliografía aborda delitos particulares, ora cometidos por la mujer, ora con la mujer 
como víctima, destacando el homicidio doloso femenino, el suicidio y la homosexualidad; también se incluyen aquellos delitos específicos perseguidos por la Inquisición (herejía, hechicería, brujería, blasfemia y otros), y la praxis judicial inquisitorial que los afectaba. Un 5,8\% de la bibliografía versa sobre los delitos de índole sexual contra la mujer, como el estupro, la violación, el rapto y secuestro de mujeres en particular doncellas y jóvenes, y similares. Un 4,4\% de la bibliografía se ocupa del Derecho penitenciario. Un $4 \%$ de los títulos introduce la perspectiva de género en delitos que cuentan con una bibliografía institucional propia (citados anteriormente). Un 3,6\% de los trabajos analiza cuestiones en relación con la discriminación jurídica en general en función de diferentes fuentes legislativas o forenses. Como puede apreciarse, la base sociológica del concepto de género da lugar a unos porcentajes cuya sistematización, cuando se pretende histórico-jurídica, presenta solapamientos e interconexiones. Podría añadirse aún un porcentaje de nada menos que el $26,4 \%$ de los títulos sobre cuestiones varias: el honor, la virginidad y la sexualidad femenina, la criminalidad de la mujer vista desde la prensa, la literatura o la sociedad, el tratamiento de las viudas, la pobreza o la marginalidad, o la visión de la mujer en general.

En cuanto al origen de la bibliografía aquí expuesta, predomina la literatura del ámbito británico y norteamericano, con un $54,1 \%$ sobre el total de las publicaciones, dominando las investigaciones sobre la historia y discriminación de la mujer durante la época contemporánea (siglos XIX y primeras décadas del siglo XX), con un 36,2\%, seguidas muy de cerca por trabajos dedicados a la época moderna, con un 35,8\%. El resto de investigaciones se centra en la mujer durante la época medieval $(11,4 \%)$, la evolución histórica de una cuestión jurídica en relación con la mujer (7,9\%), o en temas concretos no ubicados cronológicamente $(8,6 \%)$. En segundo lugar, ocupa un papel destacable (en el que influye seguramente la facilidad de localización) la bibliografía española, con un 26,8\% y dominando los estudios sobre la mujer durante la época moderna (40,5\%), seguidos de temas concretos sobre el sexo femenino $(19,8 \%)$ y el estudio de la Edad contemporánea (18,2\%). Así pues, llama la atención el protagonismo que tanto la bibliografía británica y norteamericana como la española concede a la situación de la mujer en la Edad Moderna y al concepto de género, habida cuenta de la traslación de éste último, que no siempre acompaña al planteamiento de diversas cuestiones discriminatorias teóricamente análogas. Lógicamente, la preferencia por la época contemporánea, en la que surgirá el concepto de género, disminuye los riesgos de 
anacronía. Por último, los estudios franceses ocupan casi un $13 \%$ en virtud de temas concretos o sobre la evolución histórica de aspectos criminales, seguidos de la bibliografía italiana $(4,3 \%)$, portuguesa $(1 \%)$ y alemana $(0,8 \%)$.

$* * *$

Graciela E. ABASCAL JOHNSON, "Matrimonio y sociedad: violencia conyugal en Guadalajara durante la primera mitad del siglo XIX”, en J. A. Trujillo Bretón \& F. de la Torre de la Torre \& R. N. Moreno Ramos (coord.), Entre regiones: historia, sociedad y cultura, Guadalajara (Jalisco), Universidad de Guadalajara, 2010, pp. 13-22.

Elaine S. AbELSON, When Ladies Go A-Thieving. Middle-Class Shoplifters in the Victorian Department Store, New York, Oxford University Press, 1989.

Darlene Abreu-FerReIRA, Women, Crime, and Forgiveness in Early Modern Portugal, Farnham, Ashgate, 2015.

Jeffrey S. ADLER, "My mother-in-law is to blame, but I'll walk on her neck yet': homicide in late nineteenth-century Chicago", en Journal of Social History, 31-2 (1997), pp. 253-276.

Ana Aguado Higón \& Vicenta Verdugo Martí, "Las cárceles franquistas de mujeres en Valencia: castigar, purificar y reeducar", en Studia Historica. Historia Contemporánea, 29 (2011), pp. 55-85.

María Teresa AGÜERo DíEZ, "Mujeres, marginación y pobreza en Alicante durante el siglo XVIII", en Revista de Historia Moderna. Anales de la Universidad de Alicante, 34 (2016), pp. 129-149.

Sarah AILWOOD, “'The true state of my case': the memoirs of Mrs. Anne Bailey, 1771”, en Law, Crime \& History, 6-1 (2016), pp. 37-58.

Jill N. AINSLEY, “'Some mysterious agency': women, violent crime, and the insanity acquittal in the Victorian Courtroom”, en Canadian Journal of History/Annales Canadiennes d'Histoire, 35-1 (2000), pp. 37-55.

Dolores ÁlAmo MARTELl, "La discriminación legal de la mujer en el siglo XIX”, en Revista Aequitas. Estudios sobre Historia, Derecho e Instituciones, 1 (2011), pp. 11-24. 
Robert ALLEN, “La justice pénale et les femmes, 1792-1811”, en Annales Historiques de la Révolution Française, 350 (2007), pp. 87-107.

Rayne AlLISON, “The queen's three bodies: gender, criminality, and sovereignty in the execution of Mary, Queen of Scots”, en M. Cassidy-Welch \& P. Sherlock, Practices of Gender in Late Medieval and Early Modern Europe, Turnhout, Brepols, 2008, pp. 99116.

Elisabet Almeda SAMARANCH, Corregir y castigar. El ayer y hoy de las cárceles de mujeres, Barcelona, Bellaterra, 2002.

—, "Pasado y presente de las cárceles femeninas en España", en Sociológica. Revista de Pensamiento Social, 6 (2005-2006), pp. 75-105.

Beate ALthAMMER, "Roaming men, sedentary women? The gendering of vagrancy offenses in nineteenth-century Europe", en Journal of Social History, 51-4 (2018), pp. 736-759.

María Sabina Álvarez Bezos, Violencia contra las mujeres en la Castilla del final de la Edad Media, Valladolid, Universidad de Valladolid, 2015.

—, "La carta de seguro: un instrumento de defensa de la mujer maltratada durante el reinado de los Reyes Católicos”, en Clío \& Crimen. Revista del Centro de Historia del Crimen de Durango, 12 (2015), pp. 65-89.

Milagros Álvarez URCELAY, "Mujeres y criminalidad en Guipúzcoa en el Antiguo Régimen: el caso de Bergara”, en I. Reguera Acedo \& I. Bazán Díaz \& C. González Mínguez (ed.), Marginación y exclusión social en el País Vasco, Bilbao, Universidad del País Vasco, 1999, pp. 233-250.

Eugenia S. Ambroggio, Violencia, género y honor en la Córdoba borbónica. Justicia y mecanismos informales de control social, Córdoba, Ferreyra Editor, 2013.

Anne-Claude Ambroise-REndu, “Criminelles sans visage: les femmes auteurs d'abus sexuels, 1880-2006”, en L. Cadiet \& F. Chauvaud \& C. Gauvard \& P. Schmitt-Pantel \& M. Tsikounas (dir.), Figures de femmes criminelles. De l'Antiquité à nos jours, Paris, Publications de la Sorbonne, 2010, pp. 41-56. 
Federica Ambrosini, Una gentildonna davanti al Sant'Uffizio. Il processo per eresia a Isabella della Frattina 1568-1570, Genève, Droz, 2014.

Susan D. AMUSSEN, “'Being stirred to much unquietness': violence and domestic violence in early modern England”, en Journal of Women's History, 6-2 (1994), pp. 7089.

-, "Violence, gender, and race in the seventeenth-century English atlantic", en A. E. Leonard \& K. L. Nelson (ed.), Masculinities, Childhood, Violence. Attending to Early Modern Women-and Men Proceedings of the 2006 Symposium, Newark, University of Delaware Press, 2011, pp. 283- 302.

John C. Appleby, Women and English Piracy, 1540-1720. Partners and Victims of Crime, Woodbridge, The Boydell Press, 2013.

Álvaro ARAGÓN RUANO, "Relaciones y conflictividad familiares en Guipúzcoa durante la Edad Moderna", en A. Jiménez Estrella \& J. J. Lozano Navarro (ed.), Actas de la XI Reunión Científica de la Fundación Española de Historia Moderna. Comunicaciones, Granada, Universidad de Granada, 2012, II, pp. 276-287.

Diana ArAúz MERCADO, "Solteras, casadas y viudas. La condición jurídica de las mujeres castellano-leonesas en la normativa penal (siglos XII-XIV)”, en M. I. del Val Valdivieso \& P. Martínez Sopena (coord.), Castilla y el mundo feudal. Homenaje al profesor Julio Valdeón, Valladolid, Junta de Castilla y León, III, 2009, pp. 323-344.

—, "La normativa hispano medieval y su aplicación en Indias: condición femenina dentro del marco penal y procesal”, en Estudios de Historia de España, 14 (2012), pp. 69-82.

Adolfo I. ARBElo GARCÍA, "Matrimonio y conflictividad en Canarias: una mirada desde el siglo XVIII", en A. Jiménez Estrella \& J. J. Lozano Navarro (ed.), Actas de la XI Reunión Científica de la Fundación Española de Historia Moderna. Comunicaciones, Granada, Universidad de Granada, 2012, II, pp. 288-299.

John E. ARCHER, "Men behaving badly? Masculinity and the uses of violence, 1850 1900”, en S. D’Cruze (ed.), Everyday Violence in Britain, 1850-1950. Gender and Class, Harlow, Longman, 2000, pp. 41-54. 
Carmen Argente del Castillo OcaÑA, "Cautiverio y martirio de doncellas en la Frontera", en F. Toro Ceballos \& J. Rodríguez Molina (coord), IV Estudios de frontera. Historia, tradiciones y leyendas en la frontera. Homenaje a Don Enrique Toral y Peñaranda. Congreso celebrado en Alcalá la Real en noviembre de 2001, Jaén, Diputación Provincial de Jaén, 2002, pp. 31-72.

Margaret L. ARnOt \& Cornelie Usborne (ed.), Gender and Crime in Modern Europe, London, University College London Press, 1999.

Julio Luis ARROYO VOZMEDIANO, "Maltrato de género en los procesos matrimoniales modernos. La Rioja, 1641-1713”, en A. Jiménez Estrella \& J. J. Lozano Navarro (ed.), Actas de la XI Reunión Científica de la Fundación Española de Historia Moderna. Comunicaciones, Granada, Universidad de Granada, 2012, II, pp. 311-322.

Riccardo ASTOLFI, “Femina probrosa', concubina, 'mater solitaria”, en Studia et Documenta Historiae et Iuris, 31 (1965), pp. 15-60.

Joanne BAILEY \& Loreen GIESE, "Marital cruelty: reconsidering lay attitudes in England, c. 1580 to 1850”, en The History of the Family, 18-3 (2013), pp 289-305.

Gordon M. BAKKen \& Brenda FARrington, Women Who Kill Men. California Courts, Gender, and the Press, Lincoln, University of Nebraska Press, 2009.

Daniel S. Baldellou Monclús \& Francisco José Alfaro Pérez, "Yesca y fuego. Condicionantes de la conducta sexual del servicio doméstico español en el siglo XVIII", en Hispania. Revista Española de Historia, 251 (2015), pp. 695-723.

Pompa BANERJEE, Burning Women. Widows, Witches, and Early Modern European Travelers in India, New York, Palgrave Macmillan, 2003.

Jenifer BANKS, “'A new home' for whom? Caroline Kirkland exposes domestic abuse on the Michigan frontier", en C. Daniels \& M. V. Kennedy (ed.), Over the Threshold. Intimate Violence in Early America, New York, Routledge, 1999, pp. 135-147.

Edward E. BAPTIST, “"My mind is o drown you andleave you behind'. 'Omie Wise', intimate violence, and masculinity", en C. Daniels \& M. V. Kennedy (ed.), Over the Threshold. Intimate Violence in Early America, New York, Routledge, 1999, pp. 94110. 
María Isabel BARBeito CARneIRo (ed.), Cárcel y mujeres en el siglo XVII, Madrid, Castalia, 1991.

Christine BARD \& Frédéric Chauvaud \& Michelle PERrot \& Jacques-Guy PetiT (dir.), Femmes et justice pénale. XIXe-XXe siècles, Rennes, Presses Universitaires de Rennes, 2002.

Jürgen BARKHOFF, "Female vampires, victimhood, and vengeance in German literature around 1800", en H. Fronius \& A. Linton (ed.), Women \& Death. Representations of Female Victims and Perpetrators in German Culture 1500-2000, Rochester, Camden House, 2008, pp. 128-143.

Carlos Barros GuIMERAns, "Rito y violación: derecho de pernada en la Baja Edad Media”, en Historia Social, 16 (1993), pp. 3-18.

Suzanne BARTLET, Licoricia of Winchester. Marriage, Motherhood and Murder in the Medieval Anglo-Jewish Community, London, Vallentine Mitchell, 2009.

Alana BARTON, “'Wayward girls and wicked women': two centuries of 'semi-penal' control", en Liverpool Law Review, 22, 2-3 (2000), pp. 157-171.

Alessio BASILICO, “La violenza domestica nell'Abruzzo di Età Moderna”, en Genesis. Rivista della Società Italiana delle Storiche, 9-2 (2010), pp. 57-74.

Jesse F. BATTAN, “'In the marriage bed woman's sex has been enslaved and abused': defining and exposing marital rape in late-nineteenth-century America", en Merrill D. Smith (ed.), Sex Without Consent. Rape and Sexual Coercion in America, New York London, New York University Press, 2001, pp. 204-229.

Iñaki BAZÁN DíAZ, "Mujeres, delincuencia y justicia penal en la Europa medieval. Una aproximación interpretativa", en R. Córdoba de la Llave (coord.), Mujer, marginación y violencia entre la Edad Media y los tiempos modernos, Córdoba, Universidad de Córdoba, 2006, pp. 29-74.

—, "La violencia legal del sistema penal medieval ejercida contra las mujeres", en Clío \& Crimen. Revista del Centro de Historia del Crimen de Durango, 5 (2008), pp. 203227. 
John M. BEATTIE, "The criminality of women in eighteenth-century England", en Journal of Social History, 8-4 (1975), pp. 80-116.

Brigitte H. Bechtold \& Donna Cooper Graves, "The ties that bind: infanticide, gender, and society", en History Compass, 8-7 (2010), pp. 704-717.

Deirdre BEDDOE, Welsh Convict Women. A Study of Women Transported from Wales to Australia, 1787-1852, Barry, S. Williams, 1979.

Christine BÉNAVIDÈS, Les femmes délinquantes à Madrid, 1700-1808, Toulouse, Cric, 2000.

—, "Les victimes des crimes et délits féminins à Madrid au XVIIIe siècle", en B. Garnot (dir.) Les victimes, des oubliées de l'histoire? Actes du Colloque de Dijon, 7-8 octobre 1999, Rennes, Presses Universitaires de Rennes, 2000, pp. 311-318.

Margalida BERNAT I ROCA, "Dones i revolta. La presència femenina a les Germanies (Mallorca, 1521-1523)", en Bolletí de la Societat Arqueològica Lul-liana. Revista d'Estudis Històrics, 61 (2005), pp. 71-94.

Joanne BERNIER \& André CELLARD, 'Le syndrome de la femme fatale: 'matricide' et représentation féminine au Québec, 1898-1940”, en Criminologie, 29-2 (1996), pp. 2948.

José Ramón BERTOMEU SÁNCHEZ, "El esqueleto de la viuda Houet: frenología y medicina legal en Francia durante la década de 1830”, en Criminocorpus. Varia (2015).

Linda BIEMER, "Criminal Law and women in New Amsterdam and early New York", en N. A. M. Zeller (ed.), A Beautiful and Fruitful Place. Selected Rensselaerswijck Seminar Papers, New York, New Netherland Publishing, 1991, pp. 73-82.

Maïté BILlORÉ, "Paroles de femmes violées devant la justice en Lyonnais (XVe-XVIIIe siècle)”, en L. Bodiou \& F. Chauvaud \& L. Gaussot \& M.-J. Grihom \& M. Soria (dir.), Le corps en lambeaux. Violences sexuelles et sexuées faites aux femmes, Rennes, Presses Universitaires de Rennes, 2016, pp. 345-358.

Lucy BLAnd, Modern Women on Trial. Sexual Transgression in the Age of the Flapper, Manchester, Manchester University Press, 2013.

Belén BlÁZQueZ ViLAPlana \& Isabel RAmos VÁZQueZ, "Historia jurídica de la mujer en la cárcel y políticas penitenciarias en España: pasado, presente y futuro de una 
realidad marginal bajo la perspectiva de género", en M. E. Jaime de Pablos (ed.), Identidades femeninas en un mundo plural, Almería, Arcibel Editores, 2009, pp. 91100.

Lydie BoDIOU, "Être une femme en Grèce classique: une histoire de corps contraint et contraignant", en L. Bodiou \& F. Chauvaud \& L. Gaussot \& M.-J. Grihom \& M. Soria (dir.), Le corps en lambeaux. Violences sexuelles et sexuées faites aux femmes, Rennes, Presses Universitaires de Rennes, 2016, pp. 163-176.

Lydie Bodiou \& Frédéric Chauvaud \& Ludovic GAUSSOT \& Marie-José GRIHOM \& Myriam SORIA (dir.), Le corps en lambeaux. Violences sexuelles et sexuées faites aux femmes, Rennes, Presses Universitaires de Rennes, 2016.

Maria R. BoES, "Women and the penal system in Frankfurt am Main, 1562-1696", en Criminal Justice History. An International Annual, 13 (1992), pp. 61-74.

Danièle BOHLER, "Empoisonneuses, usurpatrices et traîtresses: le bruit et la preuve (Moyen Âge français)", en L. Cadiet \& F. Chauvaud \& C. Gauvard \& P. Schmitt-Pantel \& M. Tsikounas (dir.), Figures de femmes criminelles. De l'Antiquité à nos jours, Paris, Publications de la Sorbonne, 2010, pp. 117-130.

Andrea Borgione, "Separazione coniugale e maltrattamenti domestici a Torino (18381889)", en S. Feci \& L. Schettini (a cura di), La violenza contro le donne nella storia. Contesti, linguaggi, politiche del diritto (secoli XV-XXI), Roma, Viella, 2017, pp. 87106.

Albert Borowitz, The Woman Who Murdered Black Satin. The Bermondsey Horror, Columbus, Ohio State University Press, 1981.

Ruth B. BotTigheimer, "Murdering mothers in Bible stories and fairy tales in Germany, 1550-1900", en H. Fronius \& A. Linton (ed.), Women \& Death. Representations of Female Victims and Perpetrators in German Culture 1500-2000, Rochester, Camden House, 2008, pp. 28-42.

Margaret E. BoYLE, Unruly Women. Performance, Penitence, and Punishment in Early Modern Spain, Toronto, University of Toronto Press, 2014. 
Angela Brabin, The Black Widows of Liverpool. A Chilling Account of Cold-Blooded Murder in Victorian Liverpool, Lancaster, Palatine, 2003.

Isabel M. R. Mendes Drumond BRAGA, "Género e confisco inquisitorial no Portugal moderno: da legislação à prática”, en M. Torremocha Hernández \& A. Corada Alonso (ed.), La mujer en la balanza de la justicia (Castilla y Portugal, siglos XVII y XVIII), Valladolid, Castilla, 2017, pp. 181-196.

Isabel M. R. Mendes Drumond BragA \& Margarita ToRremochA HernándeZ (coord.), As mulheres perante os tribunais do Antigo Regime na Península Ibérica, Coimbra, Universidade de Coimbra, 2015.

Paulo Drumond BrAgA, "Criminalidade feminina e perdão régio em Portugal na Época Moderna”, en I. M. R. M. D. Braga \& M. Torremocha Hernández (coord.), As mulheres perante os tribunais do Antigo Regime na Península Ibérica, Coimbra, Universidade de Coimbra, 2015, pp. 111-118.

Ian BRAND \& Mark STANIFORTH, "Care and control: female convict transportation voyages to Van Diemen's Land, 1818-1853", en The Great Circle. Journal of the Australian Association for Maritime History, 13-2 (1991), pp. 23-42.

Susan Branson, Dangerous to Know. Women, Crime, and Notoriety in the Early Republic, Philadelphia, University of Pennsylvania Press, 2008.

Sigrid BraUner, Fearless Wives \& Frightened Shrews. The Construction of the Witch in Early Modern Germany, Amherst, University of Massachusetts Press, 1995.

Yseult Bridges, Poison and Adelaide Bartlett. The Pimlico Poisoning Case, London, Huthinson, 1962.

Françoise BRIEGEL, "La clémence du glaive: plaider pour les criminels au siècle des Lumières à Genève", en Crime, Histoire \& Sociétés, 4-1 (2000), 9-29.

Nicole BROCARD, "Henriette de Crans, sorcière, hérétique, invocatrice de 'dyables' et empoisonneuse", en L. Bodiou \& F. Chauvaud \& M. Soria (dir.), Les Vénéneuses. Figures d'empoisonneuses de l'Antiquité à nos jours, Rennes, Presses Universitaires de Rennes, 2015, pp. 339-348. 
Judith C. Brown, Immodest Acts. The Life of a Lesbian Nun in Renaissance Italy, New York - Oxford, Oxford University Press, 1986.

—, Soeur Benedetta entre sainte et lesbienne. Toscane XVIIe siècle, Paris, Gallimard, 1987.

Yvonne Galloway Brown \& Rona Ferguson (ed.), Twisted Sisters. Women, Crime and Deviance in Scotland since 1400, East Linton, Tuckwell Press, 2002.

Robert M. BUFFINGTON, "La violencia contra la mujer y la subjetividad masculina en la prensa popular de la ciudad de México en el cambio de siglo", en C. Agostoni \& E. Speckman Guerra (ed.), De normas y transgresiones. Enfermedad y crimen en América Latina (1850-1950), Mexico City, Universidad Nacional Autónoma de México, 2005, pp. 287-325.

Susanna BURGHARTZ, "The equation of women and witches: a case study of witchcraft trials in Lucerne and Lausanne in the fifteenth and sixteenth centuries", en R. J. Evans (hg.), The German Underworld. Deviants and Outcasts in German History, London, Routledge, 1988, pp. 57-74.

Trevor BURNARD, "Theater of terror. Domestic violence in Thomas Thistlewood's Jamaica, 1750-1786”, en C. Daniels \& M. V. Kennedy (ed.), Over the Threshold. Intimate Violence in Early America, New York, Routledge, 1999, pp. 237-253.

Jacky BuRNETT, 'Exposing 'the inner life': the Women's Co-operative Guild's attitude to “cruelty”, en S. D’Cruze (ed.), Everyday Violence in Britain, 1850-1950. Gender and Class, Harlow, Longman, 2000, pp. 136-154.

Victoria BuRRows, "Desire and the (re)-presentation of the lesbian body in history", en Limina. A Journal of Historical and Cultural Studies, 1 (1995), pp. 33-46.

Anne M. Butler, Daughters of Joy, Sisters of Misery. Prostitutes in the American West, 1865-90, Urbana, University of Illinois Press, 1985.

—, Gendered Justice in the American West. Women Prisoners in Men's Penitentiaries, Urbana, University of Illinois Press, 1997.

—, "Women, suicide, and the jury in later medieval England", en Signs. Journal of Women in Culture and Society, 32-1 (2006), pp. 141-166. 
—, The Language of Abuse. Marital Violence in Later Medieval England, Leiden, Brill, 2007.

-, "The haunting of Isabell Binnington: ghosts of murder, texts, and Law in Restoration England”, en Journal of British Studies, 50-2 (2011), pp. 248-276.

Lucie ButTEX, "L’indulgence des juges? La femme incriminée à Genève au siècle des Lumières. Genre et répression pénales (1767-1792)”, en Crime, Histoire \& Sociétés, 191 (2015), pp. 41-65. [en línea en mayo 2018]

Loïc Cadiet \& Frédéric Chauvaud \& Claude Gauvard \& Pauline SchmitT-Pantel \& Myriam Tsikounas (dir.), Figures de femmes criminelles. De l'Antiquité à nos jours, Paris, Publications de la Sorbonne, 2010.

Caitlin G. Callaghan, "Seven shillings and a penny: female suicide in late medieval England”, en Medieval Feminist Forum, 43-1 (2007), pp. 88-107.

Kathy CALlaHAN, "Women who kill: an analysis of cases in late eighteenth- and early nineteenth-century London”, en Journal of Social History, 46-4 (2013), pp. 1013-1038.

Alessandra CAMERANO, "Donne oneste o meretrici? Incertezza dell'identità fra testamenti e diritto di proprietà a Roma”, en Quaderni Storici, 99 (1998), pp. 637-675.

María del Juncal CAMPO GUINEA, "Tolerar y reglamentar: la mala vida y la condición femenina en Pamplona al final del siglo XIX”, en Huarte de San Juan. Geografía e Historia, 5 (1998), pp. 63-72.

María Luisa CANDAU CHACÓN, "La mujer, el matrimonio y la justicia eclesiástica. Adulterio y malos tratos en la archidiócesis hispalense. Siglos XVII y XVIII", en Andalucía medieval. Actas del III Congreso de Historia de Andalucía, Córdoba, Publicaciones Obra Social y Cultural Cajasur, 2002, I, pp. 218-230.

—, "Mujeres ante la justicia: bígamas en la Sevilla Moderna", en Historia et Ius. Rivista di Storia Giuridica dell'Età Medievale e Moderna, 9 (2016), pp. 1-14.

Enrique CANTERA Montenegro, "Malos tratos y violencia doméstica entre los judeoconversos hispanos en el tránsito de la Edad Media a la Moderna”, en Espacio, Tiempo y Forma. Serie III. Historia Medieval, 20 (2007), pp. 29-42. 
Bernard CAPP, When Gossips Meet. Women, Family, and Neighbourhood in Early Modern England, Oxford, Oxford University Press, 2003.

Coline CARDi \& Geneviève PRUvost (coord.), Penser la violence des femmes, Paris, La Découverte, 2012.

Calum CARMICHAEL, “Women's offences and Biblical Law”, en Forum Historiae Iuris (14.02.1998), pp. 1-11.

Carmen Carracedo Falagán, La mujer en el Derecho penal castellano del Antiguo Régimen, Oviedo, Universidad de Oviedo, 1990.

Jean-Pierre CARreZ, "La Salpêtrière de Paris sous l'Ancien Régime: lieu d'exclusion et de punition pour femmes", en Criminocorpus. Varia (2008).

Maria Grazia CASALI, "Donne, confessori e Inquisizione romana. Indagini preliminari intorno al reato della 'sollicitatio ad turpia' a Lodi”, en Annali di Storia Moderna e Contemporanea, 10 (2004), pp. 221-267.

Cesarina CASAnova, Per forza o per amore. Storia della violenza familiare nell'età moderna, Roma, Salerno Editrice, 2016.

—, "Crimini di donne, giudici benevoli (Bologna XVI-XVIII secolo)", en Historia et Ius. Rivista di Storia Giuridica dell'Età Medievale e Moderna, 9 (2016), pp. 1-11.

Adriana CASES SolA, "La violencia de género en la Segunda República", en Hispania Nova. Revista de Historia Contemporánea, 11 (2013), pp. 306-332.

110. Marisha C. CASwell, Married Women, Crime, and Questions of Liability in England, 1640-1760, Ontario, Queen's University, 2012.

—, "Mothers, wives and killers: marital status and homicide in London, 1674-1790", en R. Hillman \& P. Ruberry-Blanc (eds.), Female Transgression in Early Modern Britain. Literary and Historical Explorations, Farnham, Ashgate, 2014, pp. 107-126.

Marco CAvina, "Per una storia della "cultura della violenza coniugale", en Genesis. Rivista della Società Italiana delle Storiche, 9-2 (2010), pp. 19-37.

—, Le nozze di sangue. Storia della violenza coniugale, Roma, Laterza, 2011. 
—, "Las mujeres y la eutanasia: tipología criminal", en Historia et Ius. Rivista di Storia Giuridica dell'Età Medievale e Moderna, 9 (2016), pp. 1-10.

Joselyn Dominique CEA MATus \& Yéssica GonzÁlez GóMEZ, “Transgresión y criminalidad femenina en el departamento de Temuco 1884-1924”, en Espacio Regional. Revista de Estudios Sociales, 13 (2016), pp. 119-136.

Miguel Ángel CHAmocho CANTUdo, "El delito de sodomía femenina en la obra del Padre franciscano Sinistrati D'Ameno, 'De Sodomía Tractatus'”, en Revista de Estudios Histórico-Jurídicos, 30 (2008), pp. 387-424.

Martine CHARAGEAT, “De l'affrontement et de la violence entre époux à l'affrontement entre pouvoirs publics et pouvoir des maris à Saragosse au XVe siècle", en Cahiers d'Études Hispaniques Médiévales, 28 (2005), pp. 341-373.

—, "Décrire la violence maritale au Moyen Âge. Exemples aragonais et anglais (XIVeXVIe siècles)", en Tracés. Revue de Sciences Humaines, 19 (2010), pp. 43-63.

—, "Figures de femmes criminelles en péninsule Ibérique au Moyen Âge?", en L. Cadiet \& F. Chauvaud \& C. Gauvard \& P. Schmitt-Pantel \& M. Tsikounas (dir.), Figures de femmes criminelles. De l'Antiquité à nos jours, Paris, Publications de la Sorbonne, 2010, pp. 243-254.

—, La délinquance matrimoniale. Couples en conflit et justice en Aragon (XVe-XVIe siècle), Paris, Publications de la Sorbonne, 2011.

—, "Meurtres entre époux en péninsule Ibérique à la fin du Moyen Âge (XVe-XVIe siècles)”, en Annales de Démographie Historique, 130-2 (2015), pp. 25-50.

Jean-François CHASSAING, "Responsabilité et procès de la femme criminelle. Repères historiques", en L. Cadiet \& F. Chauvaud \& C. Gauvard \& P. Schmitt-Pantel \& M. Tsikounas (dir.), Figures de femmes criminelles. De l'Antiquité à nos jours, Paris, Publications de la Sorbonne, 2010, pp. 167-178.

123. Frédéric Chauvaud, "La confusion des sexes: l'assassinat de madame Suzanne, déserteur de la Grande Guerre", en L. Cadiet \& F. Chauvaud \& C. Gauvard \& P. Schmitt-Pantel \& M. Tsikounas (dir.), Figures de femmes criminelles. De l'Antiquité à nos jours, Paris, Publications de la Sorbonne, 2010, pp. 67-81. 
—, "Fillettes, épouses et mères brutalisées devant les tribunaux. La cruauté en famille: un acte de folie? (1880-1930)", en F. Chauvaud \& A. Rauch \& M. Tsikounas (dir.), Le sarcasme du mal. Histoire de la cruauté de la Renaissance à nos jours, Rennes, Presses Universitaires de Rennes, 2016, pp. 47-60.

—, “La preuve par l'hymen: le viol des femmes sous l'œil des médicins légistes (18101890)", en L. Bodiou \& F. Chauvaud \& L. Gaussot \& M.-J. Grihom \& M. Soria (dir.), Le corps en lambeaux. Violences sexuelles et sexuées faites aux femmes, Rennes, Presses Universitaires de Rennes, 2016, pp. 63-80.

Frédéric Chauvaud \& Gilles Malandain (dir.), Impossibles victimes, impossibles coupables. Les femmes devant la justice (XIXe-XXe siècles), Rennes, Presses Universitaires de Rennes, 2009.

Clara Chevalier, "Des émeutières passées sous silence? L'invisibilisation de la violence des femmes au prisme du genre (Paris, 1775)", en C. Cardi \& G. Pruvost (dir.), Penser la violence des femmes, Paris, La Découverte, 2012, pp. 85-94.

Anna Clark, Women's Silence, Men's Violence. Sexual Assault in England 1770-1845, London, Pandora, 1987.

-, "Domesticity and the problem of wifebeating in nineteenth-century Britain: working-class culture, Law and politics”, en S. D'Cruze (ed.), Everyday Violence in Britain, 1850-1950. Gender and Class, Harlow, Longman, 2000, pp. 27-40.

-, Women and Crime in the Street Literature of Early Modern England, Houndmills New York, Palgrave Macmillan, 2003.

Sandra CLARK, "Deeds against nature: women and crime in street literature of early modern England", en Sederi. Yearbook of the Spanish and Portuguese Society for English Renaissance Studies, 12 (2002), pp. 9-30.

Albrecht Classen (ed.), Sexual Violence and Rape in the Middle Ages. A Critical Discourse in Premodern German and European Literature, Berlin - Boston, De Gruyter, 2011.

Elisabeth ClAVERIE \& Pierre LAMAISON, L'impossible mariage. Violence et parenté en Gévaudan XVIIe, XVIIIe et XIXe siècles, Paris, Hachette, 1982. 
Sherrill CoHEn, The Evolution of Women's Asylums Since 1500. From Refuges for ExProstitutes to Shelters for Battered Women, New York, Oxford University Press, 1992.

Samuel K. CoHN, "Women in revolt in medieval and early modern Europe", en J. Firnhaber-Baker \& D. Schoenaers (ed.), The Routledge History Handbook of Medieval Revolt, London - New York, Routledge, 2017, pp. 208-219.

Jenny COLEMAN, "Incorrigible offenders. Media representations of female habitual criminals in the late Victorian and Edwardian Press", en Media History, 22-2 (2016), pp. 143-158.

María José Collantes de TeRÁn DE LA HeRA, "Particularidades del proceso inquisitorial por razón de sexo", en M. J. Zamora Calvo (ed.) Mulieres inquisitionis. La mujer frente a la Inquisición en España, Vigo, Academia del Hispanismo, 2017, pp. 105-146.

—, "La mujer en el proceso inquisitorial: hechicería, bigamia y solicitación", en Anuario de Historia del Derecho Español, 87 (2017), pp. 55-87.

Carolyn A. CONLEY, "No pedestals: women and violence in late nineteenth-century Ireland”, en Journal of Social History, 28-4 (1995), pp. 801-818.

-, Certain Other Countries. Homicide, Gender, and National Identity in Late Nineteenth-Century England, Ireland, Scotland, and Wales, Columbus, Ohio State University Press, 2007.

-, "Atonement and domestic homicide in late Victorian Scotland", en R. McMahon (ed.), Crime, Law and Popular Culture in Europe, 1500-1900, Cullompton, Willan, 2008, pp. 219-238.

Ricardo CóRDOBA DE LA LLAVE (coord.) Mujer, marginación y violencia entre la Edad Media y los tiempos modernos, Córdoba, Universidad de Córdoba, 2006.

—, "Mujer, marginación y violencia entre la Edad Media y los tiempos modernos", en R. Córdoba de la Llave (coord.), Mujer, marginación y violencia entre la Edad Media y los tiempos modernos, Córdoba, Universidad de Córdoba, 2006, pp. 7-28.

—, "Consideraciones en torno al delito de agresión sexual en la Edad Media”, en Clío \& Crimen. Revista del Centro de Historia del Crimen de Durango, 5 (2008), pp. 187-202. 
Scott CRAIG, "Women, crime and the experience of servitude in Colonial America and Australia", Limina. A Journal of Historical and Cultural Studies, 19 (2013), pp. 1-10.

Elaine F. CRANE, Killed Strangely. The Death of Rebecca Cornell, Ithaca, Cornell University ress, 2002.

-, Witches, Wife Beaters, and Whores. Common Law and Common Folk in Early America, Ithaca, Cornell University Press, 2011.

Patricia CRAWfORD \& Sara MENDELSON, "Sexual identities in early modern England: the marriage of two women in 1680", en Gender and History 7-3 (1995), pp. 362-377.

Astrid CuBANO-IGuinA, "Legal constructions of gender and violence against women in Puerto Rico under Spanis rule, 1860-1895”, en Law and History Review, 22-3 (2004), pp. 531-564.

Joy Damousi, Depraved and Disorderly. Female Convicts, Sexuality and Gender in Colonial Australia, Cambridge, Cambridge University Press, 1997.

Andrew DAVIES, "Youth gangs, masculinity and violence in late Victorian Manchester and Salford", en Journal of Social History, 32-2 (1998), pp. 349-369.

—, “These viragoes are no less cruel than the lads': young women, gangs and violence in late Victorian Manchester and Salford”, en British Journal of Criminology, 39-1 (1999), pp. 72-89.

—, "Youth gangs, gender and violence, 1870-1900", en S. D'Cruze (ed.), Everyday Violence in Britain, 1850-1950. Gender and Class, Harlow, Longman, 2000, pp. 70-85.

Cornelia H. DAYTON, "Taking the trade: abortion and gender relations in an eigteenthcentury New England village”, en The William and Mary Quarterly, 48-1 (1991), pp. $19-49$.

—, Women before the Bar. Gender, Law, \& Society in Connecticut, 1639-1789, Chapel Hill, University of North Carolina Press, 1995.

Shani D'CRUZE, Crimes of Outrage. Sex, Violence and Victorian Working Women, Dekalb, Northern Illinois University Press, 1998.

Shani D’CRUZE \& Anupama RAO (ed.), Violence, Vulnerability and Embodiment. Gender and History, Oxford, Blackwell Publishing, 2005. 
Willem DE BLÉCOURT, "The making of the female witch: reflections on witchcraft and gender in the early modern period", en Gender and History 12-2 (2000), pp. 287-309.

Giuseppina DE GIUDICI, “'La donna di fronte alla legge penale'. Il problema dell'imputabilità della donna tra Otto e Novecento", en Historia et Ius. Rivista di Storia Giuridica dell'Età Medievale e Moderna, 10 (2016), pp. 1-25.

Ruben DE LUCA, Donne assassinate. Dall'omicidio seriale allo stupro di gruppo, storia e fenomenologia della guerra condotta dal genere maschile contro 'l'altra metà del cielo', Roma, Newton Compton, 2009.

Esther DeHOUX, "Couper les seins des femmes: du supplice à la monstruosité", en L. Bodiou \& F. Chauvaud \& L. Gaussot \& M.-J. Grihom \& M. Soria (dir.), Le corps en lambeaux. Violences sexuelles et sexuées faites aux femmes, Rennes, Presses Universitaires de Rennes, 2016, pp. 191-200.

aul DeLSALLE, “'Il n'avoit point l'intention de l'occire': les femmes et la violence à travers les lettres de rémission dans le comté de Bourgogne (Franche-Comté) au début du XVIIe siècle", en A. Follain (dir.), Brutes ou braves gens? La violence et sa mesure (XVIe-XVIIIe siècle), Strasbourg, Presses Universitaires de Strasbourg, 2015, pp. 295312.

Luis DíAZ DE la GuARdia y LóPEZ, “La muerte de Doña María de Vargas”, en M. Canellas Anoz (coord), Sucesos curiosos en la Andalucía del Antiguo Régimen, Sevilla, Consejería de Cultura, 2009-2010, I, pp. 59-90.

Caroline DoDDS, "Earth women and eagle warriors: revealing aztec gender roles through ritual violence", en K. D. Watson (ed.), Assaulting the Past. Violence and Civilization in Historical Context, Newcastle, Cambridge Scholars Publishing, 2007, pp. 162-178.

L. Mara DodGE, “'One female prisoner is of more trouble than twenty males': women convicts in Illinois prisons, 1835-1896”, en Journal of Social History, 32-4 (1999), pp. 907-930.

-, 'Whores and Thieves of the Worst Kind.' A Study of Women, Crime, and Prisons, 1835-2000, Dekalb, Northern Illinois University Press, 2002.

Frances E. Dolan, Dangerous Familiars. Representations of Domestic Crime in England, 1550-1700, Ithaca, Cornell University Press, 1994. 
—, Marriage and Violence. The Early Modern Legacy, Philadelphia, University of Pennsylvania Press, 2008.

Georgina Dopico Black, Perfect Wives, Other Women. Adultery and Inquisition in Early Modern Spain, Durham, Duke University Press, 2001.

—, "Public bodies, private parts: the virgins and Magdalens of Magdalena de San Gerónimo”, en Journal of Spanish Cultural Studies, 2-1 (2001), pp. 81-96.

Julie DoYon, "Des secrets de famille aux archives de l'effraction: violences intrafamiliales et ordre judiciaire au XVIIIe siècle", en A. Follain \& B. Lemesle \& M. Nassiet \& E. Pierre \& P. Quincy-Lefebvre (dir.), La violence et le judiciaire. Discours, perceptions, pratiques, Rennes, Presses Universitaires de Rennes, 2008, pp. 209-222.

Pascale Drouet, “Appropriating a famous female offender: Mary Frith (1584?-1659), alias Moll Cutpurse", en R. Hillman \& P. Ruberry-Blanc (eds.), Female Transgression in Early Modern Britain. Literary and Historical Explorations, Farnham, Ashgate, 2014, pp. 91-104.

Adrien DuboIs, La violence des femmes en Normandie à la fin du Moyen Âge, Paris, Société Parisienne d'Histoire et d'Archéologie Normandes, 2010.

Armel DuBOIS-NAYT, "Women thieves in early modern England: what can we learn from narrative sources?”, en Études Épistémè, 14 (2008), pp. 193-206.

Caroline S. Dunn, Damsels in Distress Or Partners in Crime? The Abduction of Women in Medieval England, Ann Arbor, Fordham University, 2007.

—, Stolen Women in Medieval England. Rape, Abduction, and Adultery, 1100-1500, Cambridge, Cambridge University Press, 2013.

Alicia Duñaiturria Laguarda, "El maltrato a las mujeres en el siglo XVIII", en Clío \& Crimen. Revista del Centro de Historia del Crimen de Durango, 12 (2015), pp. 91108.

Gregory DuRSTON, Victims and Viragos. Metropolitan Women, Crime and the Eighteenth-Century Justice System, Suffolk, Arima Publishing, 2007.

-, Wicked Ladies. Provincial Women, Crime and the Eighteenth-Century English Justice System, Newcastle upon Tyne, Cambridge Scholars Publishing, 2013. 
Zoë ECKMAN, "An oppressive silence: the evolution of the raped woman in medieval France and England", en The Historian. Journal of the Undergraduate History Department at New York University, 50 (2009), pp. 68-77.

Laura F. EDWARDS, "Law, domestic violence, and the limits of patriarchal authority in the antebellum South", en The Journal of Southern History, 65-4 (1999), pp. 733-770.

Robert R. EDWARDS \& Vickie ZIEGLER (ed.), Matrons and Marginal Women in Medieval Society, Woodbridge, The Boydell Press, 1995.

Ángeles EGIDO LEÓN, "Mujeres y rojas: la condición femenina como fundamento del sistema represor. Presentación”, en Studia Historica. Historia Contemporánea, 29 (2011), pp. 19-34.

Egon Conrad ElLRICHSHAUSEN, Die uneheliche Mutterschaft im altösterreichischen Polizeirecht des 16. bis 18. Jahrhunderts, dargestellt am Tatbestand der Fornication, Berlin, Duncker \& Humblot, 1988

Mary B. W. EMMERICHS, "Trials of women for homicide in nineteenth-century England”, en Women \& Criminal Justice, 5-1 (1993), pp. 99-109.

Elizabeth EWAN, "Disorderly damsels? Women and interpersonal violence in preReformation Scotland”, en The Scottish Historical Review, 89-2 (2010), pp. 153-171.

Simona FECI \& Laura SCHETTINI (a cura di), La violenza contro le donne nella storia. Contesti, linguaggi, politiche del diritto (secoli XV-XXI), Roma, Viella, 2017.

—, "Storia e uso pubblico della violenza contro le donne", en S. Feci \& L. Schettini (a cura di), La violenza contro le donne nella storia. Contesti, linguaggi, politiche del diritto (secoli XV-XXI), Roma, Viella, 2017, pp. 7-39.

Malcolm M. FEELEY \& Hadar AVIRAM, "Social historical studies of women, crime, and courts”, en Annual Review of Law and Social Science, 6 (2010), pp. 151-171.

Malcolm M. FeELEY \& Deborah L. LitTLE, "The vanishing female. The decline of women in the criminal process, 1687-1912”, en Law \& Society Review, 25-4 (1991), pp. 719-757.

Lucia FERRANTE, "Politica e violenza di genere a Bologna nella prima età moderna. Antonia Sanvitale vs Aurelio Dall'Armi”, en S. Feci \& L. Schettini (a cura di), La 
violenza contro le donne nella storia. Contesti, linguaggi, politiche del diritto (secoli XV-XXI), Roma, Viella, 2017, pp. 43-62.

Alicia FIESTAS LOZA, "Las cárceles de mujeres”, en Historia 16, extra 7 (1978), pp. 89100.

Elizabeth FOYSTER, Marital Violence. An English Family History, 1660-1857, Cambridge, Cambridge University Press, 2005.

Martin FRANCIS, "The domestication of the male. Recent research on nineteenth- and twentieth century British masculinity”, en The Historical Journal, 45-3 (2002), pp. 637652.

Sylvie FRIGON, "L'homicide conjugal féminin, de Marie-Josephte Corriveau (1763) à Angélique Lyn Lavallée (1990): meutre ou légitime défense?”, en Criminologie, 29-2 (1996), pp. 11-27.

Helen Fronius \& Anna Linton (ed.), Women \& Death. Representations of Female Victims and Perpetrators in German Culture 1500-2000, Rochester, Camden House, 2008 .

Françoise Frontisi-DuCROuX, "Mythe et tragédie: épouses et mères sanglantes", en L. Cadiet \& F. Chauvaud \& C. Gauvard \& P. Schmitt-Pantel \& M. Tsikounas (dir.), Figures de femmes criminelles. De l'Antiquité à nos jours, Paris, Publications de la Sorbonne, 2010, pp. 101-116.

Ginger S. FROST, “She is but a woman': Kitty Byron and the English Edwardian Criminal Justice System”, en Gender and History 16-3 (2004), pp. 538-560.

—, “'He could not hold his passions': domestic violence and cohabitation in England (1850-1905)", en Crime, Histoire \& Sociétés, 12-1 (2008), pp. 45-63.

laudia GAMIÑO ESTRADA, "Las distintas caras de la violencia: mujeres, justicia y legislación en Nueva Galicia”, en J. A. Trujillo Bretón (coord.), Por el mundo del delito y sus pormenores. Historia, marginalidad y delito en América Latina, Guadalajara (Jalisco), Universidad de Guadalajara, 2018, pp. 17-51.

Kathleen E. GARAY, "Women and crime in later mediaeval England: an examination of the evidence of the Courts of Gaol Delivery, 1388 to 1409”, en Florilegium, 1 (1979), pp. 87-109. 
María del Carmen GARcía HerRero, "La marital corrección: un tipo de violencia aceptado en la Baja Edad Media", en Clío \& Crimen. Revista del Centro de Historia del Crimen de Durango, 5 (2008), pp. 39-71.

—, "Vulnerables y temidos: los varones jóvenes como grupo de riesgo para el pecado y delito en la Baja Edad Media”, en Clío \& Crimen. Revista del Centro de Historia del Crimen de Durango, 9 (2012), pp. 105-134.

Vicent M. GARÉS TIMOR, "Conflictividad social y violencia de género en la nobleza valenciana del siglo XVI. El intento fracasado de unión de los señoríos de Carlet y L'Alcúdia”, en E. Serrano Martín (coord.), De la tierra al cielo. Líneas recientes de investigación en historia moderna. I Encuentro de Jóvenes Investigadores en Historia Moderna, Zaragoza, Institución Fernando el Católico, 2013, pp. 713-729.

Benoît GARNOT, Un crime conjugal au XVIIIe siècle. L'affaire Boiveau, Paris, Imago, 1993.

Margarita GARRIDO, “Consideraciones sobre el suicidio femenino en la Antigüedad”, en CECYM. Centro de Estudios Clásicos y Medievales, Cátedra I (2003), pp. 126-132.

Mary GIBSON, "Women's prisons in Italy: a problem of citizenship", en Crime, Histoire \& Sociétés, 13-2 (2009), pp. 27-40.

Mary E. GILES (ed.), Women in the Inquisition. Spain and the New World, Baltimore, Johns Hopkins University Press, 1998.

A. Ron GILLIS, "So long as they both shall live: marital dissolution and the decline of domestic homicide in France, 1852-1909”, en American Journal of Sociology, 101-5 (1996), pp. 1273-1305.

Barry GODFREY, "Explaining gendered sentencing patterns for violent men and women in the late-Victorian and Edwardian period", en British Journal of Criminology, 45-5 (2005), pp. 696-720.

—, "A historical perspective on criminal justice responses to female and male offending", en R. Gartner \& B. McCarthy (ed.), The Oxford Handbook of Gender, Sex, and Crime, Oxford, Oxford University Press, 2014, pp. 158-174.

Dominique GodinEAU, "Femmes et violence dans l'espace politique révolutionnaire", en Historical Reflections / Réflexions Historique, 29-3 (2003), pp. 559-576. 
Rona GOFFEN, “Wives and mothers: adultery, madness, and marital misery in Titian's Paduan frescoes”, en K. Eisenbichler \& J. Murray (ed.), Desire and Discipline. Sex and Sexuality in the Premodern West, Toronto, University of Toronto Press, 1996, pp. 217 244.

Gutmaro GómEZ BRAvo, "Las prisiones de Eva. Mujer y cárcel en el siglo XIX”, en Anuario de Derecho Penal y Ciencias Penales 56-1 (2003), pp. 351-384.

Inés GómEZ GonZÁLEZ, “Los 'pecados de hombres' en los tribunales reales: los magistrados del Antiguo Régimen y los delitos contra la moral sexual”, en J.-P. Zúñiga (ed.), Negociar la obediencia. Autoridad y consentimiento en el mundo ibérico en la Edad Moderna, Granada, Comares, 2013, pp. 63-79.

María Valentina GómEz MAMPASO, "La mujer y el derecho en la España del siglo XIX: Concepción Arenal (1820-1893)”, en M. C. García-Nieto París (coord.), Ordenamiento jurídico y realidad social de las mujeres. Siglos XVI a XX. Actas de las IV Jornadas de Investigación Interdisciplinaria, Madrid, Universidad Autónoma de Madrid, 1986, pp. 239-246.

Nicole GONTHIER, "Délinquantes ou victimes, les femmes dans la société lyonnaise du XV e siècle", en Revue Historique, 271-1/549 (1984), pp. 25-46.

Rhonda M. GonZALES, "No friends in the Holy Office: black and mulatta women healing communities and answering to the Inquisition in Seventeen Century Mexico", en Journal of Pan African Studies, 6-1 (2013), pp. 1-19.

Jill T. GoodwIN, "'More deadly than the male': classifying female witnesses in trial advocacy handbooks", en College Literature, 25-1 (1998), pp. 139-162.

Laura GowING, Domestic Dangers. Women, Words, and Sex in Early Modern London, Oxford, Clarendon Press, 1996.

usan E. GRACE, Female Criminality in York and Hull 1830-1870, York, University of York, 1999.

Anne E. GRAHAM \& Carol Emmas, The Last Victim. The Extraordinary Life of Florence Maybrick, the Wife of Jack the Ripper, London, Headline, 1999.

Adeline Grand-Clement \& Sarah Rey, "Les filles de Médée. Figures de reines vénéneuses dans l'historiographie gréco-latine”, en L. Bodiou \& F. Chauvaud \& M. 
Soria (dir.), Les Vénéneuses. Figures d'empoisonneuses de l'Antiquité à nos jours, Rennes, Presses Universitaires de Rennes, 2015, pp. 151-166.

Frances GRAY, Women, Crime and Language, New York, Palgrave Macmillan, 2003.

Cecilia A. GREen, “The abandoned lower class of females': class, gender, and penal discipline in Barbados, 1875-1929", en Comparative Studies in Society and History, 531 (2011), pp. 144-179.

Elisabeth GREIF, "A crime by all means. Female same-sex sexuality in the First Republic of Austria”, en Journal on European History of Law, 4-2 (2013), pp. 76-83.

Daniel J. R. GREY, “'Who's really wicked and immoral, women or men?': uneasy classifications, Hindu gender roles and infanticide in late nineteenth-century India”, en V. Miller \& J. Campbell (ed.), Transnational Penal Cultures. New Perspectives on Discipline, Punishment and Desistance, London - New York, Routledge, 2014, pp. 3650 .

Angela GROPPI, "Il teatro della giustizia donne colpevoli e opinione pubblica nell'Italia liberale”, en Quaderni Storici, 111 (2002), pp. 649-679.

Kali N. Gross, Colored Amazons. Crime, Violence and Black Women in the City of Brotherly Love, 1880-1910, Durham, Duke University Press, 2006.

230. Patrizia GUARNIERI, "Men committing female crime: infanticide, family and honor in Italy, 1890-1981”, en Crime, Histoire \& Sociétés, 13-2 (2009), pp. 41-54.

Laurence GuignARD, "Sexe juridique? Femmes et hommes face à la justice pénale au XIX siècle", en A. Rauch \& M. Tsikounas (dir.), L'historien, le juge et l'assassin, Paris, Publications de la Sorbonne, 2012, pp. 123-139.

Pamela HAAG, “The 'ill-use of a wife': patterns of working-class violence in domestic and public New York City, 1860-1880”, en Journal of Social History, 25-3 (1992), pp. 447-477.

Danielle HaAse-Dubosc, Ravie et enlevée. De d'enlèvement des femmes comme stratégie matrimoniale au XVIIe siècle, Paris, Albin Michel, 1999.

Dianne HALL, "Words as weapons: speech, violence and gender in late medieval Ireland", Éire-Ireland. A Journal of Irish Studies, 41 1-2 (2006), pp. 122-141. 
Dianne HALL \& Elizabeth MALCOLM, "Gender, hybridity, and violence on the frontiers of late-medieval and early-modern Ireland”, en M. Cassidy-Welch \& P. Sherlock (ed.), Practices of Gender in Late Medieval and Early Modern Europe, Turnhout, Brepols, 2008, pp. 77-98.

—, "Beyond the pale: gender and violence in Ireland, 1169-1603", en J. Dülffer \& R. Frank (ed.), Peace, War and Gender from Antiquity to the Present. Cross-Cultural Perspectives, Essen, Klartext, 2009, pp. 155-168.

Barbara A. HANAWALt, "The female felon in fourteenth-century England", en Viator. Medieval and Renaissance Studies, 5 (1974), pp. 253-368.

-, "Women before the Law: females as felons and prey in fourteenth-century England", en K. Weisberg (ed.), Women and the Law. A Social Historical Perspective, Cambridge, Schenkman, 1982, I, pp. 165-195.

—, 'Of Good and Ill Repute'. Gender and Social Control in Medieval England, New York, Oxford University Press, 1998.

Chelsea D. M. HARTLEN, Managing Criminal Women in Scotland: An Assessment of the Scarcity of Female Offenders in the Records of the High Court of Justiciary, 1524-1542, Halifax, Dalhousie University, 2014.

Randa HELFIELD, "Female poisoners of the nineteenth century: a study of gender bias in the application of the Law”, en Osgoode Hall Law Journal, 28-1 (1990), pp. 53-101.

Tony Henderson, Disorderly Women in Eighteenth-Century London. Prostitution and Control in the Metropolis, 1730-1830, London, Longman, 1999.

Fernando HeRnández Holgado, “Cárceles de mujeres del novecientos. Una rutina punitiva secular", en Segle XX. Revista Catalana d'Història, 6 (2013), pp. 85-112.

Carlos Heusch “Femmes et violences dans les 'fueros' castillans du Moyen Âge", en Cahiers d'Études Hispaniques Médiévales, 28 (2005), pp. 307-339.

Solange HIBBS, Femmes criminelles et crimes de femme en Espagne (XIXe et XX e siècles), Toulouse, Lansman, 2010.

Alexandra N. HiLL, 'Bloudy Tygrisses': Murderous Women in Early Modern English Drama and Popular Literature, Orlando, University of Central Florida, 2009. 
Richard HILlman, “Criminalizing the woman's incest: 'Pericles' and its analogues”, en R. Hillman \& P. Ruberry-Blanc (eds.), Female Transgression in Early Modern Britain. Literary and Historical Explorations, Farnham, Ashgate, 2014, pp. 15-28.

Steve HINDLE, “The shaming of Margaret Knowsley: gossip, gender and the experience of authority in early modern England", en Continuity and Change, 9-3 (1994), pp. 391419.

Katharine HodgKIN (ed.), Women, Madness and Sin in Early Modern England. The Autobiographical Writings of Dionys Fitzherbert, Farnham - Burlington, Ashgate, 2010.

Sharon HowARD, Gender and Defamation in York, 1661-1700: Reputation, Authority and the Power of Words, York, University of York, 1999.

Damigela HoXHA, "Donne criminali fra dottrina e prassi alla fine del XVIII secolo", en Historia et Ius. Rivista di Storia Giuridica dell'Età Medievale e Moderna, 9 (2016), pp. $1-9$.

Annmarie Hughes, "The 'non-criminal' class: wife-beating in Scotland (c. 18001949)", en Crime, Histoire \& Sociétés, 14-2 (2010), pp. 31-54.

Isabel V. HuLL, "Sexualstrafrecht und geschlechtsspezifische Normen in den deutschen Staaten des 17. und 18. Jahrhunderts", en U. Gerhard (hg.), Frauen in der Geschichte des Rechts. Von der Frühen Neuzeit bis zur Gegenwart, Munich, Beck, 1997, pp. 221234.

N. E. H. Hull, Female Felons. Women and Serious Crime in Colonial Massachusetts, Urbana, University of Illinois Press, 1987.

Margaret HUNT, “Wife beating, domesticity and women's independence in eighteenthcentury London”, en Gender \& History, 4-1 (1992), pp. 10-33.

Elisabet HUNTINGFORD ANTIGAS, "Violencia contra las mujeres en las imágenes griegas”, en M. D. Molas Font (ed.), Violencia deliberada. Las raíces de la violencia patriarcal, Barcelona, Icaria, 2007, pp. 121-134.

Jennine HURL-EAMON, "Domestic violence prosecuted: women binding over their husbands for assault at Westminster Quarter Sessions, 1685-1720", en Journal of Family History, 26-4 (2001), pp. 435-454. 
—, Gender and Petty Violence in London, 1680-1720, Columbus, Ohio State University Press, 2005.

Jennine HurL-EAMON \& Sonya LIPSETT-RIVERA, "Spiralling out of control? Female violence in eighteenth-century London and Mexico", en K. D. Watson (ed.), Assaulting the Past. Violence and Civilization in Historical Context, Newcastle, Cambridge Scholars Publishing, 2007, pp. 179-202.

Martín IBARRA BeNLlOCH, "El suicidio de la mujer en la 'Historia Eclesiastica' de Eusebio de Cesarea", en Congreso de Jóvenes Historiadores y Geógrafos. Actas I, Madrid, Universidad Complutense, 1990, pp. 569-576.

Juan José IGLESIAS RODRÍGUEZ, "Conflictos y resistencias femeninas. Mujeres y justicia en la España Moderna”, en M. Torremocha Hernández \& A. Corada Alonso (ed.), La mujer en la balanza de la justicia (Castilla y Portugal, siglos XVII y XVIII), Valladolid, Castilla, 2017, pp. 13-50.

María del Mar JimÉnEZ EstACiO, "Los orígenes de las cárceles de mujeres en España: las Galeras", en M. Cabrera Espinosa \& J. A. López Cordero (dir.), VI Congreso virtual sobre Historia de las Mujeres. (Del 15 al 31 de octubre de 2014), Jaén, Archivo Histórico Diocesano de Jaén, 2014, pp. 1-27.

Karen Margaret JONES, Gender, crime and the Local Courts in Kent, 1460-1560, Greenwich, University of Greenwich, 2001.

Cheryl T. Kalny, 'Daughters of Eve': Female Offenders and the Criminal Justice System, St. Paul 1858-1929, Ann Arbor, Marquette University, 1989.

Martine KALUSZYNSKI, "La femme (criminelle) sous le regard du savant au XIXe siècle", en C. Cardi \& G. Pruvost (dir.), Penser la violence des femmes, Paris, La Découverte, 2012, pp. 286-299.

Sari Katajala-PeltomaA, "A good wife?: demonic possession and discourses of gender in late medieval culture", en M. G. Muravyeva \& R. M. Toivo (ed.), Gender in Late Medieval and Early Modern Europe, New York - Abingdon, Routledge, 2013, pp. 73-88.

Jennifer KeRMODE \& Garthine WALKeR (ed.), Women, Crime and the Courts in Early Modern England, Chapel Hill, University of North Carolina Press, 1994. 
Anne-Marie KILDAY, Women and Violent Crime in Enlightenment Scotland, Woodbridge, The Boydell Press, 2007.

—, “The lady-killers': homicidal women in early modern Britain”, en K. D. Watson (ed.), Assaulting the Past. Violence and Civilization in Historical Context, Newcastle, Cambridge Scholars Publishing, 2007, pp. 203-220.

—, “That women ar but men's shadows': examining gender, violence and criminality in early modern Britain”, en M. G. Muravyeva \& R. M. Toivo (ed.), Gender in Late Medieval and Early Modern Europe, New York - Abingdon, Routledge, 2013, pp. 5369.

—, “Angels with dirty faces': violent women in early modern Scotland”, en R. Hillman \& P. Ruberry-Blanc (eds.), Female Transgression in Early Modern Britain. Literary and Historical Explorations, Farnham, Ashgate, 2014, pp. 141-162.

-, "Constructing the cult of the criminal: Kate Webster - Victorian murderess and media sensation", en A.-M. Kilday \& D. Nash (ed.), Law, Crime \& Deviance Since 1700. Micro-Studies in the History of Crime, London, Bloomsbury, 2017, pp. 125-147.

Andrew J. KING, "Constructing gender: sexual slander in nineteenth-century America", en Law and History Review, 13-1 (1995), pp. 63-110.

Peter KING, "Female offenders, work and life-cycle change in late-eighteenth-century London", en Continuity and Change, 11-1 (1996), pp. 61-90.

Daniel KLERMAN, "Women prosecutors in thirteenth-century England", en Yale Journal of Law \& the Humanities, 14-2 (2002), pp. 271-319.

Jezabel KoCH, "Margen y marginalidad: los espacios de actuación de las mujeres castellanas (siglos XIV a XVI)", en Fundación. Revista Fundación para la Historia de España, 12 (2014-2015), pp. 345-354.

Sharon A. Kowalsky, Deviant Women. Female Crime and Criminology in Revolutionary Russia, 1880-1930, DeKalb, Northern Illinois University Press, 2009.

Odile KRAKOVITCH, Les femmes bagnardes, Paris, O. Orban, 1990.

Lawrence KrAMER, "Murderous women in German opera", en H. Fronius \& A. Linton (ed.), Women \& Death. Representations of Female Victims and Perpetrators in German Culture 1500-2000, Rochester, Camden House, 2008, pp. 144-156. 
Howard I. KUSHNER, "Suicide, gender, and the fear of modernity in nineteenth-century medical and social thought”, en Journal of Social History, 26-3 (1993), pp. 461-490.

Luigi Labruna, "Donne e pene in Roma antica", en Index. Quaderni Camerti di Studi Romanistici International Survey of Roman Law, 40 (2012), pp. 1-18.

Nicola LACEY, Women, Crime, and Character. From Moll Flanders to Tess of the d'Urbervilles, Oxford, Oxford University Press, 2008.

André LACHANCE, "Women and crime in Canada in the early eighteenth century, 17121759”, en L. A. Knafla (ed.), Crime and Criminal Justice in Europe and Canada, Waterloo, Wilfred Laurier University Press, 1981, pp. 157-178.

Frédérique LANGUE, "Las mantuanas escandalosas. Irreverencia y transgresiones femeninas en la aristocracia venezolana del siglo XVIII", en F. Morales Padrón (coord.), XIII Coloquio de Historia Canario-Americana. VIII Congreso Internacional de Historia de America (AEA), 1998, Las Palmas de Gran Canaria, Ediciones del Cabildo de Gran Canaria, 2000, pp. 1352-1363.

Jocelyne LEBLOIS-HAPPE, "La sanction des femmes criminelles. Y a-t-il une spécificité féminine de la peine?”, en L. Cadiet \& F. Chauvaud \& C. Gauvard \& P. Schmitt-Pantel \& M. Tsikounas (dir.), Figures de femmes criminelles. De l'Antiquité à nos jours, Paris, Publications de la Sorbonne, 2010, pp. 179-196.

Jocelyne LÉGARÉ, "La condition juridique des femmes ou l'historique d'une 'affaire de famille"”, en Criminologie, 16-2 (1983), pp. 7-26.

Satu LiDMAN, "Shaming for honour. Women and early modern legal culture in Courts and homes", en B. Sère \& J. Wettlaufer (ed.) Shame Between Punishment and Penance. The Social Usages of Shame in the Middle Ages and Early Modern Times, Firenze, Sismel - Edizioni del Galluzzo, 2013, pp. 309-328.

—, "Violence or justice? Gender-specific structures and strategies in Early Modern Europe", en The History of the Family, 18-3 (2013), pp. 238-260.

Jonas LILIEQUIST, "Changing discourses of marital violence in Sweden from the Age of Reformation to the late nineteenth century", en Gender \& History, 23-1 (2011), pp. 125. 
Anne Logan, Feminism and Criminal Justice. A Historical Perspective, Basingstoke, Palgrave Macmillan, 2008.

Maria Antónia LOPES, "Mulheres condenadas à morte em Portugal: de 1693 à abolição da pena última”, en I. M. R. M. D. Braga \& M. Torremocha Hernández (coord.), As mulheres perante os tribunais do Antigo Regime na Península Ibérica, Coimbra, Universidade de Coimbra, 2015, pp. 119-145.

Victoria LÓPEZ BARAHONA, "La caza de vagabundas: trabajo y reclusión en Madrid durante la Edad Moderna”, en P. Oliver Olmo \& J. C. Urda Lozano (coord.), La prisión y las instituciones punitivas en la investigación histórica, Cuenca, Universidad de Castilla-La Mancha, 2014, pp. 31-47.

Raquel LÓPEZ MERCHÁN, "La violencia contra la mujer: evolución terminológica en España”, en Clío \& Crimen. Revista del Centro de Historia del Crimen de Durango, 12 (2015), pp. 109-123.

Miguel Luis LÓPEZ-GUADALUPE MuÑOZ, "Violencia y mujer en Granada en la primera mitad del siglo XVII", en Les Cahiers de Framespa. Nouveaux Champs de l'Histoire Sociale, 12 (2013), pp. 1-22.

Pedro Luis LoREnZo CADARSO, "Los malos tratos a las mujeres en Castilla en el siglo XVII”, en Brocar. Cuadernos de Investigación Histórica, 15 (1989), pp. 119-136.

Carlos LozAno RuIZ, "Los delitos contra la propiedad cometidos por las mozas de servicio en Castilla a finales del Antiguo Régimen”, en I. M. R. M. D. Braga \& M. Torremocha Hernández (coord.), As mulheres perante os tribunais do Antigo Regime na Península Ibérica, Coimbra, Universidade de Coimbra, 2015, pp. 177-199.

Leo LUCASSEN, "The police, gender, and social control: German servants in Dutch towns, 1918-1940”, en C. Emsley \& E. Johnson \& P. Spierenburg (ed.), Social Control in Europe. 2. 1800-2000, Columbus, Ohio State University Press, 2004, pp. 226-244.

Douglas MacGowan, The Strange Affair of Madeleine Smith. Victorian Scotland's Trial of the Century, Edinburgh, Mercat Press, 2007.

Alonso Manuel MaCíAs DomínguEz, “Conflictividad matrimonial en el arzobispado de Sevilla durante la Edad Moderna”, en A. Jiménez Estrella \& J. J. Lozano Navarro (ed.), Actas de la XI Reunión Científica de la Fundación Española de Historia Moderna. Comunicaciones, Granada, Universidad de Granada, 2012, II, pp. 474-486. 
Marta MADERo EguíA, "Savoirs féminins et construction de la vérité: les femmes dans la preuve testimoniale en Castille au XIIIe siècle", en Crime, Histoire \& Sociétés, 3-2 (1999), pp. 5-21.

Linda MAHOOD, Policing Gender, Class and Family. Britain, 1800-1945, London, University College London Press, 1995.

Jessica L. Malay, The Case of Mistress Mary Hampson. Her Story of Marital Abuse and Defiance in Seventeenth-Century England, Stanford, Stanford University Press, 2014.

Andrew Mangham, Violent Women and Sensation Fiction. Crime, Medicine and Victorian Popular Culture, Basingstoke, Palgrave Macmillan, 2007.

Tomás A. MAntecón Movellán, "Mujeres forzadas y abusos deshonestos en la Castilla moderna", en Manuscrits. Revista d'Història Moderna, 20 (2002), pp. 157-185.

—, 'Las mujeres ante los tribunales castellanos: 'acción de justicia' y 'usos de la penalidad' en el Antiguo Régimen", en Chronica Nova. Revista de Historia Moderna de la Universidad de Granada, 37 (2011), pp. 99-123.

Susanna MANTIONI, “'Homo mulieri lupus'. Susan Brownmiller e la demistificazione della 'cultura solidale con lo stupro", en S. Feci \& L. Schettini (a cura di), La violenza contro le donne nella storia. Contesti, linguaggi, politiche del diritto (secoli XV-XXI), Roma, Viella, 2017, pp. 139-152.

Randall MARTIN, Women, Murder, and Equity in Early Modern England, Hoboken, Taylor \& Francis, 2007.

Scott C. MARTIN, "Violence, gender, and intemperance in early national Connecticut", en Journal of Social History, 34-2 (2000), pp. 309-325.

Alfredo Martín GarcíA, "Matrimonio y violencia doméstica en la España Moderna", en O. Fernández Álvarez (ed.), Mujeres en riesgo de exclusión social y violencia de género, León, Universidad de León, 2014, pp. 449-466.

—, "Transgresiones femeninas, violencia y conflicto en la jurisdicción de Marina del Departamento de Ferrol a finales del Antiguo Régimen”, en M. Torremocha Hernández \& A. Corada Alonso (ed.), La mujer en la balanza de la justicia (Castilla y Portugal, siglos XVII y XVIII), Valladolid, Castilla, 2017, pp. 197-221. 
Gema MARTínez GALINDO, "Las cárceles de mujeres en la época de la Constitución de Cádiz", en J. Ma. Terradillos Basoco (coord.), Marginalidad, cárcel, las "otras" creencias: primeros desarrollos jurídicos de "La Pepa", Cádiz, Diputación de Cádiz, 2008, pp. 91-116.

Manuel MARTínez MARTíneZ, "Clamor y rebeldía. Las mujeres gitanas durante el proyecto de exterminio de 1749”, en Historia y Política, 40 (2018), pp. 25-51.

María Victoria MARTINS RODRÍGUEZ, "Cárceles y mujeres en Galicia durante el franquismo", en Studia Historica. Historia Contemporánea, 29 (2011), pp. 87-117.

, "Violencia e trauma do franquismo: unha perspectiva de xénero", en F. Suárez Golán \& A. Cabana Iglesia (coord.), Historia, cultura, violencia. Actas do X Curso de Primavera. Lugo, 22-25 de abril de 2014, Santiago de Compostela, Universidade de Santiago de Compostela, 2015, pp. 68-82.

Lorna MCLEAN, “'Deserving' wives and 'drunken' husbands: wife beating, marital conduct, and the Law in Ontario, 1850-1910", en Histoire Sociale / Social History, 69 (2002), pp. 59-80.

Jacob MELISH, "Women and the courts in the control of violence between men: evidence from a Parisian neighborhood under Louis XIV", en French Historical Studies, 33-1 (2010), pp. 1-31.

Doris Mendlewitsch (hg.), Von Ladies, Leichen und Ganoven. Kriminalgeschichten aus dem 19. Jahrhundert, Düsseldorf, Econ Taschenbuch, 1994.

Roberto MENDOZA, "Sobre la delincuencia femenina en Castilla a fines de la Edad Media”, en R. Córdoba de la Llave (coord.), Mujer, marginación y violencia entre la Edad Media y los tiempos modernos, Córdoba, Universidad de Córdoba, 2006, pp. 75126.

—, "Mujeres adúlteras en la Castilla medieval. Delincuentes y víctimas", en Clío \& Crimen. Revista del Centro de Historia del Crimen de Durango, 5 (2008), pp. 151-186.

Rosa María MentXaka Elexpe, “Género y violencia(s) en la 'Pasión' de Perpetua y Felicidad”, en Index. Quaderni Camerti di Studi Romanistici International Survey of Roman Law, 40 (2012), pp. 447-474. 
Robert MEnzIES \& Dorothy E. ChunN, "The gender politics of criminal insanity: 'order-in-council' women in British Columbia, 1888-1950', en Histoire Sociale / Social History, 62 (1998), pp. 241-279.

Rafael M. MÉRIDA JiMÉNEZ, “Mujer, sodomía e Inquisición”, en M. J. Zamora Calvo (ed.) Mulieres inquisitionis. La mujer frente a la Inquisición en España, Vigo, Academia del Hispanismo, 2017, pp. 215-238.

Marija Mogorović CRLJENKo, "The abduction of women for marriage: Istria at the beginning of the seventeenth century", en Acta Histriae, 22-3 (2014), pp. 617-632.

Gemma Moreno NAVARro, "La participació de les dones a la germania de València", en Clapir. Joves Historiadors i Historiadores Valencians, Febrer 2015, pp. 1-7.

Milagros MORO IPOLA, "Violencia y maltrato en la familia romana y sus consecuencias: la adolescencia perdida de Tiberio Claudio", en Espacio, Tiempo y Forma. Serie II. Historia Antigua, 21 (2008), pp. 275-285.

María José MuÑOZ GARCíA, "Violencia domestica en 1854 'por no hacer las cosas como se las mandaba”, en M. J. Muñoz García \& M. J. Torquemada Sánchez, Tres estampas sobre la mujer en la historia del derecho, Madrid, Dykinson, 2013, pp. 115161.

Marianna MURAVYEVA, “'A king in his own household': domestic discipline and family violence in early modern Europe reconsidered", en The History of the Family, 18-3 (2013) pp. 227-237.

Jacqueline MurRay \& Nicholas TERPSTRA (ed.), Sex, Gender and Sexuality in Renaissance Italy, Abingdon - New York, Routledge, 2019.

Victoria M. NAGY, "Narratives in the courtroom: female poisoners in mid-nineteenth century England", en European Journal of Criminology, 11-2 (2014), pp. 213-227.

José Ramón NARVÁEZ HERNÁNDEZ, “"None of the women were abused': indigenous contexts for the treatment of women captives in the Northeast", en Merrill D. Smith (ed.), Sex Without Consent. Rape and Sexual Coercion in America, New York London, New York University Press, 2001, pp. 10-26. 
—, "Gendering moral crimes in early modern England and Europe - Blashphemy the mirror image of witchcraft?", en M. G. Muravyeva \& R. M. Toivo (ed.), Gender in Late Medieval and Early Modern Europe, New York, Routledge, 2013, pp. 153-169.

Mary NASH, "Género, cambio social y la problemática del aborto", en Historia Social, 2 (1988), pp. 19-36.

Janet L. NELSON \& Alice Rio, "Women and laws in early medieval Europe", en J. M. Bennett \& R. M. Karras (ed.), The Oxford Handbook of Women and Gender in Medieval Europe, Oxford, Oxford University Press, 2013, pp. 103-117.

Daniela Novarese, "Donne e violenza sessuale in Italia, un lungo, tormentato percorso normativo: 'La giustizia era altrettanto violenta degli stupratori"', en M. Torremocha Hernández \& A. Corada Alonso (coord.), El estupro. Delito, mujer y sociedad en el Antiguo Régimen, Valladolid, Universidad de Valladolid, 2018, pp. 283-311.

Ricardo Pessa de OliveIRA, "Criminalidade feminina nas visitas pastorais da diocese de Coimbra. O caso da paróquia de Pombal (1649-1805)", en I. M. R. M. D. Braga \& M. Torremocha Hernández (coord.), As mulheres perante os tribunais do Antigo Regime na Península Ibérica, Coimbra, Universidade de Coimbra, 2015, pp. 63-84.

Pedro Oliver Olmo, “Genealogía de la 'corrigenda': mujeres encarceladas en Pamplona (siglos XVI-XIX)”, en Huarte de San Juan. Geografía e Historia, 5 (1998), pp. 7-42.

Marta ORTEGA BALANZA, "Delitos relacionados con la función procreadora femenina en las leyes del Próximo Oriente antiguo", en M. D. Molas Font (ed.), Violencia deliberada. Las raíces de la violencia patriarcal, Barcelona, Icaria, 2007, pp. 71-88.

Ana E. ORTEGa BAÚn, "Honor femenino, manipulación de la fama y sexualidad en la Castilla de entre 1200 y 1550", en Clío \& Crimen. Revista del Centro de Historia del Crimen de Durango, 13 (2016), pp. 75-98.

Pedro ORTEGo GiL, “Condenas a mujeres en la Edad Moderna: aspectos jurídicos básicos para su compresión”, en Historia et Ius. Rivista di Storia Giuridica dell'Età Medievale e Moderna, 9 (2016), pp. 1-17.

Alejandra Palafox MenegazzI, "Género, mujeres y sexualidad delictiva entre el antiguo y el nuevo régimen mexicano. Un balance historiográfico", en Chronica Nova. Revista de Historia Moderna de la Universidad de Granada, 43 (2017), pp. 335-361. 
Deirdre PALK, Gender, Crime and Discretion in the English Criminal Justice System, 1780s to 1830s, Leicester, University of Leicester, 2001.

—, "Fit objects for mercy': gender, the bank of England and currency criminals, 18041833, en Women's Writing, 11-2 (2004), pp. 237-258.

—, Gender, Crime and Judicial Discretion, 1780-1830, Woodbridge, The Boydell Press, 2006.

William PALMER, "Gender, violence, and rebellion in Tudor and early Stuart Ireland", en The Sixteenth Century Journal. The Journal of Early Modern Studies, 23-4 (1992), pp. 699-712.

Pilar PAVÓN TORREJón, "Mujeres, delitos y condenas en cuatro leyendas romanas", en Habis, 37 (2006), pp. 287-300.

—, 'Prácticas abusivas en la 'domus' reguladas por la legislación de Adriano (D. 1.6.2 y 48.9.5)", en Studia et Documenta Historiae et Iuris, 76 (2010), pp. 135-146.

—, "El uxoricidio de 'Iulia Maiana, manu mariti interfecta' (CIL XIII, 2182)", en Habis, 42 (2011), pp. 253-262.

Amparo PedRegal RodríGuez, "Las mártires cristianas: género, violencia y dominación del cuerpo femenino", en Studia Historica. Historia Antigua, 18 (2000), pp. 277-294.

—, "Mal-tratadas por los dioses: las raíces religiosas de la violencia contra las mujeres", en Y. Fontanil Gómez \& M. A. Alcedo Rodríguez \& J. Roberts (coord.), Análisis interdisciplinar de la violencia de género, Oviedo, Krk, 2013, pp. 37-46.

Cristina de Pedro Álvarez \& Rubén Pallol Trigueros, "Rapto de novias, rebeldía sexual y autoridad familiar. Discursos y conflictos en torno a la crisis del orden de los sexos en la sociedad urbana de comienzos del siglo XX”, en Clío \& Crimen. Revista del Centro de Historia del Crimen de Durango, 13 (2016), pp. 289-306.

María Luisa Pedrós CiURANA, "La magia femenina en la Valencia del siglo XVIII. Primeras aproximaciones", en Estudis. Revista de Historia Moderna, 37 (2011), pp. 377-391.

María José PÉrez Álvarez, "Mujeres y conflictividad judicial en el León del siglo XVIII”, en M. Torremocha Hernández \& A. Corada Alonso (ed.), La mujer en la 
balanza de la justicia (Castilla y Portugal, siglos XVII y XVIII), Valladolid, Castilla, 2017, pp. 111-132.

Pablo PÉREZ García, "Las mujeres y las germanías de Valencia”, en R. Córdoba de la Llave (coord.), Mujer, marginación y violencia entre la Edad Media y los tiempos modernos, Córdoba, Universidad de Córdoba, 2006, pp. 311-332.

María Isabel PÉREZ De Colosía Rodríguez, "La mujer y el Santo Oficio de Granada durante la segunda mitad del siglo XVI", en M. C. García-Nieto París (coord.), Ordenamiento jurídico y realidad social de las mujeres. Siglos XVI a XX. Actas de las IV Jornadas de Investigación Interdisciplinaria, Madrid, Universidad Autónoma de Madrid, 1986, pp. 55-70.

—, "Mujeres procesadas por el Tribunal del Santo Oficio de Granada", en Baética. Estudios de Arte, Geografía e Historia, 27 (2005), pp. 423-436.

Mary Elizabeth PerRY, Gender and Disorder in Early Modern Seville, Princeton, Princeton University Press, 1990.

Jan PETERS, "Frauen vor Gericht in einer märkischen Gutsherrschaft (2. Hälfte des 17. Jahrhunderts)", en O. Ulbricht (hg.), Von Huren und Rabenmüttern. Weibliche Kriminalität in der Frühen Neuzeit, Köln, Böhlau, 1995, pp. 231-258.

Annik PORTEAU-BITKER, "Criminalité et délinquance féminines dans le Droit pénal des XIIIe et XIVe siècles”, en Revue Historique de Droit Français et Étranger, 58-4 (1980), pp. 13-56.

Helmut PUFF, "Female sodomy: the trial of Katherina Hetzeldorfer (1477)", en Journal of Medieval and Early Modern Studies, 30-1 (2000), pp. 41-61.

Raúl RAMíREZ RUIZ, "Estudio sobre la violencia contra la mujer en el primer tercio del siglo XX: la provincia de Córdoba", en Arenal. Revista de Historia de las Mujeres, 22-1 (2015), pp. 121-155.

Isabel RAMOS VÁzQUEZ, La mujer en la cárcel. Historia jurídica y políticas penitenciarias en España, Córdoba, Universidad de Córdoba, 2011.

Sylvain RAPPAPORT, "Les femmes et la chaîne des forçats: l'impossible absence", en Revue d'Histoire Moderne et Contemporaine, 55-4 (2008), pp. 34-56. 
Mona RAUTELIN, "Female serial killers in the early modern age? Recurrent infanticide in Finland 1750-1896", en The History of the Family, 18-3 (2013), pp. 349-370.

Marion REDER GADOW, "Mujeres en las barricadas durante la guera de la Independencia (1808-1814): la rondeña María García 'la Tinajera”’, en Dossiers Feministes, 15 (2011), pp. 9-25.

Christophe ReginA, La violence des femmes. Histoire d'un tabou social, Paris, Max Milo, 2011.

—, Genre, moeurs et justice. Les Marseillaises et la violence au XVIIIe siècle, Aix-enProvence, Presses Universitaires de Provence, 2015.

Iñaki REGUERA ACEDO, "Malos tratos y violencia conyugal en la sociedad vasca de la Edad Moderna”, en Memoria y Civilización, 16 (2013), pp. 137-174.

Elizabeth REIS, Damned Women. Sinners and Witches in Puritan New England, Ithaca, Cornell University Press, 1997.

Anna RoBERTS (ed.), Violence against Women in Medieval Text, Gainesville, University Press of Florida, 1998.

Ángel RODRÍGUEZ GALLARDO, “Mujeres en prisión durante la dictadura portuguesa”, en Studia Historica. Historia Contemporánea, 29 (2011), pp. 337-366.

Helen Rogers, "Women and prison”, en Women. A Cultural Review, 27-4 (2016), pp. 469-472.

María Isabel Romero RuIZ, "Fallen women and the London Lock Hospital Laws and By-laws of 1840 (revised 1848)", en Journal of English Studies, 8 (2010), pp. 141-158.

—, "Gender policy, the London Lock Asylum Committee (1836-1842) and the Asylum Regulations for 1840", en Atlantis. A Journal of the Spanish Association for AngloAmerican Studies, 33-2 (2011), pp. 123-136.

Sylvia Romeu Alfaro, "La mujer en el Derecho penal valenciano", en Estudios dedicados a Juan Peset Aleixandre, Valencia, Universidad de Valencia, 1982, III, pp. 459-473.

Paul S. RopP \& Paola ZAMPERIni \& Harriet T. Zurndorfer (ed.), Passionate Women. Female Suicide in Late Imperial China, Leiden, Brill, 2001. 
Isabella RosonI, "La criminalità femminile nel Novecento. La realtà italiana e il caso marchigiano", en Proposte e Ricerche, 50 (2003), pp. 282-293.

Randolph RоTH, "Gender, sex, and intimate-partner violence in historical perspective", en R. Gartner \& B. McCarthy (ed.), The Oxford Handbook of Gender, Sex, and Crime, Oxford, Oxford University Press, 2014, pp. 175-190.

Diane RousSEL, "La description des violences féminines dans les archives criminelles au XVIe siècle”, en Tracés. Revue de Sciences Humaines, 19 (2010), pp. 65-81.

—, "Au grand scandale et déshonneur des femmes de bien. Justice, honneur féminin et transgressions sexuelles à Saint-Germain-des-Prés au XVIe siècle”, en H. Drévillon \& D. Venturino (dir.), Penser et vivre l'honneur à l'époque moderne, Rennes, Presses Universitaires de Rennes, 2011, p. 219-236.

Judith Rowbотнам, "Gendering protest: delineating the boundaries of acceptable everyday violence in nineteenth-century Britain", en European Review of History. Revue Européenne d'Histoire, 20-6 (2013), pp. 945-966.

-, Crime, Violence and Visibility. Gendering Understandings of Violence, Disorder and Protest in England and Wales 1784-2010, London, Routledge, 2015.

Alison RowLANDS, "Gender, ungodly parents and a witch family in seventeenth-century Germany”, en Past \& Present, 232-1 (2016), pp. 45-86.

Steven RugGLES, "Fallen women: the inmates of the Magdalen Society Asylum of Philadelphia, 1836-1908”, en Journal of Social History, 16-4 (1983), pp. 65-82.

Javier RuIZ Astiz, "La participación de las mujeres en los desórdenes públicos: análisis de su presencia en la Navarra moderna”, en Sancho El Sabio. Revista de Cultura e Investigación Vasca, 33 (2010), pp. 11-34.

—, "Mujeres ultrajadas: abusos sexuales en la Sangüesa del Antiguo Régimen”, en Zangotzarra, 14 (2010) pp. 11-111.

Flocel SABATE I CuRull, "Femmes et violence dans la Catalogne du XIVe siècle", en Annales du Midi. Revue de la France Méridionale, 207 (1994), pp. 277-316.

Karine SALOMÉ, "La terroriste: une nouvelle figure de la femme criminelle? Laure Grouvelle, Germaine Berton", en L. Cadiet \& F. Chauvaud \& C. Gauvard \& P. Schmitt- 
Pantel \& M. Tsikounas (dir.), Figures de femmes criminelles. De l'Antiquité à nos jours, Paris, Publications de la Sorbonne, 2010, pp. 57-66.

—, "Le procès de Laure Grouvelle. Mise en scène, postures et représentations autour de la violence politique des femmes sous la monarchie de Juillet", en L. Faggion \& C. Regina \& B. Ribémont (dir.), La culture judiciaire. Discours, représentations et usages de la justice du Moyen Âge à nos jours, Dijon, Éditions Universitaires de Dijon, 2014, pp. 93-108.

Élisabeth SALVI, “Femme coutumière a voler': récidive et pénalité dans le pays de Vaud à la fin de l'Ancien Régime (1740-1797)", en F. Briegel \& M. Porret (dir.), Le criminel endurci. Récidive et récidivistes du Moyen Âge au XXe siècle, Genève, Droz, 2006, pp. 153-168.

Maria Encarna SANAHUJA YLL, "Mujeres y violencia en la prehistoria", en M. D. Molas Font (ed.), Violencia deliberada. Las raíces de la violencia patriarcal, Barcelona, Icaria, 2007, pp. 27-38.

José SÁnchez-Arcilla Bernal, "La delincuencia femenina en México a finales del siglo XVIII", en Cuadernos de Historia del Derecho, 20 (2013), pp. 89-154.

Francisco Javier SÁNCHEZ-CID GORI, La violencia contra la mujer en la Sevilla del Siglo de Oro (1569-1626), Sevilla, Universidad de Sevilla, 2011.

José SÁnCHEZ HerRero, "El miedo a la mujer: las mujeres violentas", en Espacio, Tiempo y Forma. Serie III. Historia Medieval, 28 (2015), pp. 487-514.

María Helena SÁnchez OrTegA, "La mujer como fuente del mal; el maleficio", en Manuscrits. Revista d'Història Moderna, 9 (1991), pp. 41-81.

—, La mujer y la sexualidad en el Antiguo Régimen. La perspectiva inquisitorial, Madrid, Akal, 1992.

—, "La 'pecadora' como disidente social", en A. Vaca Lorenzo (ed.), Disidentes, heterodoxos y marginados en la historia, Salamanca, Universidad de Salamanca, 1998, pp. 145-180.

Margarita SÁNCHEZ ROMERO, "Mujeres y estrategias pacíficas de resolución de conflictos: el anàlisis de las sociedades prehistóricas", en M. D. Molas Font (ed.), 
Violencia deliberada. Las raíces de la violencia patriarcal, Barcelona, Icaria, 2007, pp. $39-56$.

Adelina SARRIÓN MORA, Beatas y endemoniadas. Mujeres heterodoxas ante la Inquisición siglos XVI al XIX, Madrid, Alianza Editorial, 2003.

—, "Mujeres, heterodoxia e Inquisición", en Á. Castro Sánchez \& J. A. Egea Aranda \& R. M. García Naranjo \& Ó. Morales Pérez \& E. J. Navarro Martínez (coord.), Franciscanos, místicos, herejes y alumbrados, Córdoba, Universidad de Córdoba Séneca Editorial, 2010, pp. 103-132.

—, "Mujeres procesadas por la Inquisición”, en M. J. Zamora Calvo \& A. Ortiz (ed.), Espejo de brujas. Mujeres transgresoras a través de la historia, Madrid, Abada, 2012, pp. 335-352.

—, "La beata de Villar de Águila", en M. J. Zamora Calvo (ed.) Mulieres inquisitionis. La mujer frente a la Inquisición en España, Vigo, Academia del Hispanismo, 2017, pp. 341-380.

Cristina SEgura Graiño, "La violencia sobre las mujeres en la Edad Media. Estado de la cuestión”, en Clío \& Crimen. Revista del Centro de Historia del Crimen de Durango, 5 (2008), pp. 24-38.

Félix SEgURA URRA, "Víctimas y agresoras: la mujer ante la Justicia en Navarra durante la primera mitad del siglo XIV”, en C. Erro Gasca \& I. Mugueta Moreno (ed.), Grupos sociales en Navarra. Relaciones y derechos a lo largo de la historia. Actas del V Congreso de Historia de Navarra, Pamplona, 10-13 Septiembre de 2002, Pamplona, Eunate, 2002, I, pp. 147-166.

Ann-Louise SHAPIRO, "Disordered bodies/disorderly acts: medical discourse and the female criminal in $19^{\text {th }}$-century Paris", en Genders, 4 (1989), pp. 68-86.

James A. SHARPE, "Women and violence in seventeenth- and eighteenth-century England: evidence from the Cheshire Court of Great Sessions”, en R. Hillman \& P. Ruberry-Blanc (eds.), Female Transgression in Early Modern Britain. Literary and Historical Explorations, Farnham, Ashgate, 2014, pp. 127-140.

—, "Women, proof and evidence in English infanticide cases in the later seventeenth and eighteenth centuries", en J.-P. Schandeler \& N. Vienne-Guerrin (textes réunis par), 
Les usages de la preuve d'Henri Etienne à Jeremy Bentham, Paris, Hermann, 2014, pp. 225-244.

Diana C. Silverman, The Life of Cunizza da Romano: a Study of Marriage and Violence in Dante's Italy, New York, Columbia University, 2008.

-, "Marriage and political violence in the chronicles of the medieval Veneto", en Speculum. A Journal of Medieval Studies, 86-3 (2011), pp. 652-687.

Terri L. SNYDER, “As if there was not master or woman in the land'. Gender, dependency, and household violence in Virginia, 1646-1720”, en C. Daniels \& M. V. Kennedy (ed.), Over the Threshold. Intimate Violence in Early America, New York, Routledge, 1999, pp. 219-236.

—, "Sexual consent and sexual coercion in seventeenth-century Virginia," en Merrill D. Smith (ed.), Sex Without Consent. Rape and Sexual Coercion in America, New York London, New York University Press, 2001, pp. 46-60.

—, Brabbling Women. Disorderly Speech and the Law in Early Virginia, Ithaca, Cornell University Press, 2003.

Richard D. SonN, "Gender and political violence in nineteenth-century France and Russia”, en Journal of the Western Society for French History, 28 (2000), pp. 199-206.

-, Gender and Political Violence in Nineteenth-Century France and Russia, Ann Arbor, University of Michigan, 2000.

María Jesús Souto Blanco, “A persecución política da muller: lucenses detidas no cárcere proviincial de Lugo (1936-1940)", en X. L. Axeitos Agrelo \& E. Grandío Seoane \& R. Villares Paz (ed.), A patria enteira. Homenaxe a Xosé Ramón Barreiro Fernández, Santiago de Compostela - A Coruña, Universidade de Santiago de Compostela - Consello da Cultura Galega - Real Academia Galega, 2008, pp. 343-360.

—, "Género y compromiso. Estudio de la represión judicial ejercida sobre la mujer a raíz del estallido de la subrevación militar del 20 de julio de 1936 en Lugo”, en Sémata. Ciencias Sociais e Humanidades, 20 (2008), pp. 243-266.

—, "Polo que fixeron e polo que eran. A represion direncta e a represión transitiva contra as mulleres na Guerra Civil”, en M. García-Fernández \& S. Cernadas Martínez \& A. Ballesteros Fernández (ed.), As mulleres na historia de Galicia. Actas do I Encontro 
Interdisciplinar de Historia de Xénero, 2011 Santiago de Compostela, Santiago de Compostela, Andavira, 2012, I, pp. 217-234.

Laura SPENCE, Women who Murder in Early Modern England, 1558-1700, Coventry, University of Warwick, 2010.

Pieter SPIERENBURG, "How violent were women? Court cases in Amsterdam, 16501810”, en Crime, Histoire \& Sociétés, 1-1 (1997), pp. 9-28.

-, (ed.) Men and Violence. Gender, Honor and Rituals in Modern Europe and America, Columbus, Ohio State University Press, 1998.

—, "Masculinity, violence and honor: an introduction", en P. Spierenburg (ed.) Men and Violence. Gender, Honor and Rituals in Modern Europe and America, Columbus, Ohio State University Press, 1998, pp. 1-29.

—, "Violencia, género y entorno urbano: Amsterdam en los siglos XVII y XVIII", en J.

I. Fortea Pérez \& J. E. Gelabert González \& T. A. Mantecón Movellán (ed.), Furor et rabies. Violencia, conflicto y marginación en la Edad Moderna, Santander, Universidad de Cantabria, 2002, pp. 99-128.

Amy G. SREBnick, "L'assassinat et le mystère de Mary Rogers: sexualité, crime et culture au le milieu du dix-neuvième siècle dans la ville de New York", en A. Corbin (ed.), Violences Sexuelles, Paris, Imago, 1989, pp. 113-134.

—, The Mysterious Death of Mary Rogers. Sex and Culture in Nineteenth-Century New York, New York - Oxford, Oxford University Press, 1995.

Carolyn STRANGE, "Femininities and masculinities: looking backward and moving forward in criminal legal historical gender research", en M. D. Dubber \& C. L. Tomlins (ed.), The Oxford Handbook of Legal History, Oxford, Oxford University Press, 2018, pp. 221-242.

Kristina STRAub, Domestic Affairs. Intimacy, Eroticism, and Violence between Servants and Masters in Eighteenth-Century Britain, Baltimore, Johns Hopkins University Press, 2009.

Sharon T. STROCCHIA, "Women on the edge: madness, possession, and suicide in early modern convents", en The Journal of Medieval and Early Modern Studies, 45-1 (2015), pp. 53-77. 
Jean-François TANGUY, "Les victimes de violences conjugales en Bretagne au XIXe siècle", en B. Garnot (dir.) Les victimes, des oubliées de l'histoire? Actes du Colloque de Dijon, 7-8 octobre 1999, Rennes, Presses Universitaires de Rennes, 2000, pp. 259277.

Scott K. TAYLOR, "Women, honor, and violence in a Castilian town, 1600-1650", en The Sixteenth Century Journal. The Journal of Early Modern Studies, 35-4 (2004), pp. 1079-1097.

Nicholas Terpstra, Lost Girls. Sex and Death in Renaissance Florence, Baltimore, Johns Hopkins University Press, 2010.

Janet M. THEISS, "Female suicide, subjectivity and the state in eighteenth-century China", en Gender and History 16-3 (2004), pp. 513-537.

—, "Explaining the shrew: narratives of spousal violence and the critique of masculinity in 18th-century criminal cases", en R. E. Hegel \& K. N. Carlitz (ed.), Writing and Law in Late Imperial China. Crime, Conflict, and Judgment, Seattle, University of Washington Press, 2007, pp. 44-63.

Beverly A. TLuSTY, "Gender and alcohol use in early modern Augsburg", en Histoire Sociale / Social History, 54 (1994), pp. 241-259.

Raisa M. ToIVO, "Gender, sex and cultures of trouble in witchcraft studies: European historiography with special reference to Finland", en M. Nenonen \& Raisa M. Toivo (ed.), Writing Witch-Hunt Histories. Challenging the Paradigm, Leiden, Brill, 2014, pp. 87-108.

Sofía Torallas Tovar \& José Domingo RodríGuez Martín, "La violencia de género en los papiros del Egipto grecorromano: divorcio y maltrato en el Egipto romano y bizantino", en M. D. Molas Font (ed.), Violencia deliberada. Las raíces de la violencia patriarcal, Barcelona, Icaria, 2007, pp. 161-175.

María Jesús TORQUEMADA SÁNCHEZ, "Esposas y amantes en el ámbito de la Inquisición”, en Cuadernos de Historia del Derecho, 2 (1995), pp. 253-263.

—, "Homosexualidad femenina y masculina en relación con el delito de sortilegios", en eHumanista, 26 (2014), pp. 87-115. 
Zeb TORTORICI, "Sexual violence, predatory masculinity, and medical testimony in New Spain”, en Osiris, 30-1 (2015), pp. 272-294.

Nicholas B. Tosney, "Women and 'false coining' in Early Modern London", en The London Journal. A Review of Metropolitan Society Past and Present, 32-2 (2007), pp. 103-123.

Randolph TRUMBACH, "Sex, gender, and sexual identity in modern culture: male sodomy and female prostitution in enlightenment London", en Journal of the History of Sexuality, 2-2 (1991), pp. 186-203.

-, Sex and the Gender Revolution. Volume One. Heterosexuality and the Third Gender in Enlightenment London, Chicago - London, University of Chicago Press, 1998.

Joanne TURNER, "Punishing women, 1880-1905", en The Howard Journal of Criminal Justice, 50-5 (2011), pp. 505-515.

—, "Summary justice for women: Stafford Borough, 1880-1905", en Crime, Histoire \& Sociétés, 16-2 (2012), pp. 55-77.

—, “'Rough' women: female perpetrators of common assault, England c. 1880-1900”, en M. Pluskota (ed.), Women's Criminality. Patterns and Variations in Europe, 16001914, Cambridge, Cambridge University Press. [En preparación]

Joanne TURNER \& Helen JOHNSTON, "Female prisoners, aftercare and release: residential provision and support in late nineteenth-century England”, en British Journal of Community Justice, 13-3 (2015), pp. 35-50.

Ronaldo VAINFAS \& Zeb TORTORICI, "Female homoeroticism, heresy, and the Holy Office in Colonial Brazil", en Z. Tortorici (ed.), Sexuality and the Unnatural in Colonial Latin America, Oakland, University of California Press, 2016, pp. 77-92.

Manon VAN DER HEIJDEN, "Women as victims of sexual and domestic violence in seventeenth-century Holland: criminal case of rape, incest, and maltreatment in Rotterdamm and Delft", en Journal of Social History, 33-3 (2000), pp. 623-644.

—, "Women, violence and urban justice in Holland, c. 1600-1838", Crime, Histoire \& Sociétés, 17-2 (2013), pp. 71-100.

—, "Domestic violence, alcohol abuse and the uses of justice in early modern Holland", en Annales de Démographie Historique, 130-2 (2015), pp. 69-85. 
—, "Women and crime, 1750-2000”, en P. Knepper \& A. Johansen (ed.), The Oxford Handbook of the History of Crime and Criminal Justice, New York, Oxford University Press, 2016, pp. 250-267.

Manon VAN DER HeIJDEN \& Valentijn KOnINGSBERger, "Continuity or change? Female crime in the $19^{\text {th }}$-Century Netherlands", en Crime, Histoire \& Sociétés, 17-1 (2013), pp. 101-127.

Manon VAN DER HeIJDEN \& Sanne MuURLing, "Violence and gender in eighteenthcentury Bologna and Rotterdam”, en Journal of Social History, 51-4 (2018), pp. 695716.

Manon VAN DER HEIJDEN \& Marion PlusKotA, "Leniency versus toughening? The prosecution of male and female violence in 19th century Holland", en Journal of Social History, ¿? (2015), pp. 1-16.

-, "Introduction to crime and gender in history", en Journal of Social History, 51-4 (2018), pp. 661-671.

Klaus VAN EICKELS, "Gendered Violence: Castration and Blinding as Punishment for Treason in Normandy and Anglo-Norman England”, en Gender and History 16-3 (2004), pp. 588-602.

Martha VICINUS, "Lesbian Perversity and Victorian Marriage: the 1864 Codrington Divorce Trial”, en Journal of British Studies, 36-1 (1997), pp. 70-98.

Mara R. WADE, Gender Matters. Discourses of Violence in Early Modern Literature and the Arts, Amsterdam, Rodopi, 2014.

David WAIMAN, "Mujeres marginadas. El caso de las concubinas castellanas", en Mirabilia. Revista Electrônica de História Antiga e Medieval, 21 (2015), pp. 1-14.

Garthine WALKER, “'Demons in female form': representations of women and gender in murder pamphlets of the late sixteenth and early seventeenth centuries", en W. Zunder \& S. Trill (ed.), Writing and the English Renaissance, London - New York, Longman, 1996, pp. 123-39.

—, Crime, Gender and Social Order in Early Modern England, New York, Cambridge University Press, 2003. 
Alan Watson, "Religious and Gender Discrimination: St. Ambrose and the Valentiniani”, en Studia et Documenta Historiae et Iuris, 61 (1995), pp. 313-326.

Katherine D. WATSON, "Women, violent crime and criminal justice in Georgian Wales”, en Continuity and Change, 28-2 (2013), pp. 245-272.

Tammy C. Whitlock, Crime, Gender and Consumer Culture in Nineteenth-Century England, Aldershot, Ashgate, 2005.

—, "Masculinities and crime in historical perspective", en R. Gartner \& B. McCarthy, The Oxford Handbook of Gender, Sex, and Crime, Oxford, Oxford University Press, 2014, pp. 191-206.

James H. WiLliams, "Coerced sex and gendered violence in New Netherland", en Merrill D. Smith (ed.), Sex Without Consent. Rape and Sexual Coercion in America, New York - London, New York University Press, 2001, pp. 61-80.

Lucy WILLIAMS, "Writing wayward women: why blog the history of Victorian England's female offenders?", en Law, Crime \& History, 5-1 (2015), pp. 43-53.

Samantha WiLliams, Poverty, Gender and Life-Cycle under the English Poor Law, 1760-1834, Woodbridge, The Boydell Press, 2011.

Patrick WiLson, Murderess. A Study of the Women Executed in Britain since 1843, London, Joseph, 1971.

Lucia ZEDNER, Women, Crime, and Custody in Victorian England, New York, Oxford University Press, 1991.

—, "Women, crime and penal responses: a historical account", en Crime and Justice. A Review of Research, 14 (1991), pp. 307-362. 